NBER WORKING PAPER SERIES

MYTHS AND REALITIES OF AMERICAN POLITICAL GEOGRAPHY

Edward L. Glaeser

Bryce A. Ward

Working Paper 11857

http://www.nber.org/papers/w11857

NATIONAL BUREAU OF ECONOMIC RESEARCH

1050 Massachusetts Avenue

Cambridge, MA 02138

December 2005

Glaeser thanks the Taubman Center for State and Local Government. We are grateful to Alice Chen and Nate Rosenberg, Jr. for outstanding research assistance. The views expressed herein are those of the author(s) and do not necessarily reflect the views of the National Bureau of Economic Research.

(C)2005 by Edward L. Glaeser and Bryce A. Ward. All rights reserved. Short sections of text, not to exceed two paragraphs, may be quoted without explicit permission provided that full credit, including $\odot$ notice, is given to the source. 
Myths and Realities of American Political Geography

Edward L. Glaeser and Bryce A. Ward

NBER Working Paper No. 11857

December 2005

JEL No. H7

\begin{abstract}
$\underline{\text { ABSTRACT }}$
The division of America into red states and blue states misleadingly suggests that states are split into two camps, but along most dimensions, like political orientation, states are on a continuum. By historical standards, the number of swing states is not particularly low, and America's cultural divisions are not increasing. But despite the flaws of the red state/blue state framework, it does contain two profound truths. First, the heterogeneity of beliefs and attitudes across the United States is enormous and has always been so. Second, political divisions are becoming increasingly religious and cultural. The rise of religious politics is not without precedent, but rather returns us to the preNew Deal norm. Religious political divisions are so common because religious groups provide politicians the opportunity to send targeted messages that excite their base.

Edward L. Glaeser

Department of Economics

315A Littauer Center

Harvard University

Cambridge, MA 02138

and NBER

eglaeser@harvard.edu

Bryce A. Ward

Department of Economics

Littauer Center

Harvard University

Cambridge, MA 02138

bward@fas.harvard.edu
\end{abstract}


In the aftermath of the 2000 election, David Brooks wrote in the Atlantic Monthly that America was split into red states and blue states. In red states, people believed in God, watched NASCAR and voted for George W. Bush. In blue states, people ate Thai food, cared about the environment and voted for Albert Gore. The 2004 election, which seemed geographically to be a replay of 2000 , only reinforced the perceived value of this framework. Only three states (Iowa, New Hampshire and New Mexico) switched parties between the elections.

In this essay, we revisit America's political geography and ask what is true and false about the "red state/blue state" framework. We begin by identifying five myths associated with this framework: 1) America is divided into two politically homogenous regions; 2) The two parties are more spatially segregated than in the past; 3) America's political geography is more stable than in the past; 4) America's cultural divisions are increasing and 5) America is becoming more politically polarized.

But despite the myths surrounding the red state/blue state paradigm, there are two important truths captured by this framework. America is a country with remarkable geographic diversity in its habits and beliefs. People in different states have wildly different views about religion, homosexuality, AIDS, military policy and wildly different consumption patterns. The distribution of states along all dimensions is continuous, not bimodal, but this continuum should never be confused with homogeneity. Moreover, America's ideological diversity is not particularly new. In the 1930s, New England was much more socially liberal than the South. The extent and permanence of cultural divisions across space is one of America's most remarkable features. While spatial sorting on the basis of income or tastes may seem natural to most economists, the remarkable spatial heterogeneity of beliefs - political and otherwise - presents more of a challenge to the standard Bayesian models of belief formation. For example, in the April 2004, CBS/New York Times poll, twenty-three percent of respondents in Oregon, Washington and California thought that Saddam Hussein was personally involved in the September 11, 2001, attacks. Forty-seven percent of respondents in Texas, Oklahoma and Arkansas had that view. In the 1987-2003 PEW Values surveys, 56 percent of 
Mississippi residents think that AIDS is God's punishment for immoral sexual behavior. Only 16 percent of Rhode Island residents share that view.

Using state and county level regressions, we explore a number of different hypotheses about the long run historical causes of differences in beliefs over space. We find little support these cultural differences represent long-standing differences in religiosity or the legacy of slavery.

Instead, our regressions support the idea that Blue State culture reflects primarily the legacy of different ethnicities working together at high densities: the most important historical explanatory variables are the share of the labor force in manufacturing in 1920 and the share of the population that was foreign born in 1920 strongly predict liberal beliefs and voting for John Kerry. We interpret these results as suggesting that the liberal views that reduced traditional social divisions came about because there were gains to reducing economic and religious conflicts that could derail interactions in the marketplace.

The second important truth captured by the red state/blue state framework is that political parties and politicians have had an increasing tendency to divide on cultural and religious issues rather than on economic differences. Again, in historical perspective, cultural politics is not unusual. In the late $19^{\text {th }}$ century, "Rum, Romanism and rebellion" were the core issues that determined the Republican Party. The true aberration was the midtwentieth century era of economic politics.

Why has culture dominated politics so much more effectively than economics during much of American history? Glaeser, Ponzetto and Shapiro (2005), following Downs (1957), present a model where extremism occurs because political divisions are needed to mobilize infra-marginal voters, but going to extremes is only rational when political messages are heard disproportionately by your own supporters. Political divisions therefore follow social cleavages because social organizations allow politicians to send targeted messages. This models helps us to understand why economic divisions between 
the parties only became entrenched in the middle $20^{\text {th }}$ century, with the rise of the labor movement and its growing connection to the Democratic Party, and why as unions have lost their importance, religion has again come to dominate political debate.

\section{Myths of American Political Geography}

We now discuss five myths of American political geography.

\section{Myth \# 1: America is divided into two politically homogeneous areas}

Does the red state/blue state paradigm that describes the remarkable spatial configuration of Democrats on the coast and Republicans in the heartland mean that Americans are increasingly living in politically homogenous states, so that a smaller number of people live in swing states? Is it true, as E. J. Dionne (2003) asserted, that "the red states get redder, the blue states get bluer," and as a result elections are being decided by a smaller and smaller number of battleground states?

Figure 1 shows the time series of the share of electoral votes in "battleground" states, where we define battlegrounds as those states with margin of victory that was less than ten percent. Alternative definitions from five to twenty percent margins of victory show similar results. The dotted line shows the share of electoral votes in battleground states in every election from 1840 until today. The black line shows the average of the past five elections. The gray line at the bottom of the figure shows the popular vote "margin of victory" in the last election.

The election-by-election results show that there is a great deal of volatility in the share of electoral votes, or population, connected with battleground states. In close elections, such as 1960, 1968 and 1976, more than 70 percent of the electoral votes were cast in battlegrounds. In blowout elections, like 1964 or 1972, less than fifteen percent of the votes are in such states. In the last three elections, between 40 and 50 percent of the 
electoral votes were in swing states. These numbers lie between the high and low extremes of the last 40 years.

To show any trends that underlie this volatility, the black line in Figure 1 displays the twenty year moving average of the share of electoral votes in battleground states. The moving average shows no evidence of a general downward trend in the number of swing states. Instead, the time series suggests three periods in post-1840 U.S. electoral history. Between 1840 and 1900, on average, around 55 percent of the electoral votes lived in swing states. Between 1904 and 1948, around 30 percent of electoral votes were in swing states. After 1952, the U.S. has reverted to pre-1900 patterns. The first half of the $20^{\text {th }}$ century, not today, had an unusual abundance of landslide states.

\section{Myth \# 2: The two parties are more spatially segregated than in the past}

Even though the number of states that can by considered "safe" for either party has not been rising over time, there could be more political segregation at the local level. However, the county-level evidence shows that segregation by party is not significantly increasing, and it is in fact much lower than many other forms of segregation.

There are two usual indices of racial segregation that can also be used to measure political segregation: dissimilarity and isolation. The dissimilarity index measures the share of the total population of either group 1 or group 2 that would need to be moved across areas for there to be an equal proportion of group 1 in every area. ${ }^{1}$ A high dissimilarity index indicates a large degree of segregation; if a large share of the population must move in order to be evenly distributed, then the population must currently be highly segregated. The isolation index measures the share of the population belonging to group 1 where the average member of group 1 lives. A high isolation index

1. The dissimilarity index between group 1 and group 2 is defined as:

$$
\text { Dissimilarity }=\frac{1}{2} \sum_{\text {All Areas }}\left|\frac{\text { Population }_{1, \text { Area }}}{\text { Population }_{1, \text { Total }}}-\frac{\text { Population }_{2, \text { Area }}}{\text { Population }_{2, \text { Total }}}\right|
$$

where refers to the population of group $\mathrm{i}$ for $\mathrm{i}=1$ or 2 in a geographic area and refers to the total population of group $i$. 
also indicates a large degree of segregation; if the typical member of group 1 lives in an area where the proportion of group 1 greatly exceeds the proportion of group 1 in the total population, then the population is highly segregated. ${ }^{2}$

Following Klinkner (2004), we calculate dissimilarity indices and isolation indices for Republicans and Democrats based on voting in the last presidential election between 1840 and today. ${ }^{3}$ In all cases, we have eliminated individuals who voted for neither Republican nor Democratic candidates. We use counties as the units of observation. Figure 2 shows the time patterns of these indices.

The dissimilarity index shows that there have been two time periods where the U.S. was unusually divided spatially: the elections of 1856 and 1860, when dissimilarity topped 40 percent and the geographically based Civil War ensued, and 1924, when dissimilarity was greater than 30 percent. Over the last 60 years, dissimilarity has generally been below 20 percent. The past four elections do show a slight upward trend, but this is nothing like the remarkable rise seen between 1916 and 1924. Moreover, this level of dissimilarity is much less than the dissimilarity of college and non-college educated adults across counties (.25) or blacks and non-blacks (.46).

The isolation measures show even less of a trend. Both Republicans and Democrats live in counties where about fifty percent of the voters share their own party. The isolation index in 2004 was 53.4 percent for Republicans and 52.6 percent for Democrats. These numbers are far lower than the Republican 1920s, when the average Republican lived in a county where 70 percent of the voters also voted for Coolidge or Hoover, or the Democratic 1930s where the average Democrat lived in a county where 60 percent of the voters supported F.D.R. There is just no sense that people are generally living in politically highly segregated counties.

2 The isolation index of group 1 is defined as:

$$
\text { Isolation }=\sum_{\text {All Areas }} \frac{\text { Population }_{1, \text { Area }}}{\text { Population }_{1, \text { Total }}} \frac{\text { Population }_{1, \text { Area }}}{\text { Population }_{1, \text { Area }}+\text { Population }_{2, \text { Area }}}
$$

${ }^{3}$ For years prior to 1856 , the segregation indices represent the segregation between Whigs and Democrats. 


\section{Myth \# 3: America's political geography is more stable than in the past}

While the segregation of the political parties hasn't increased significantly, it may still be true that American political divisions are hardening, and that political patterns are becoming more permanent. As Harold Meyerson (2004) wrote in the Washington Post, "the battle lines of the cultural civil war that emerged in the 2000 contest have shown themselves to be all but permeable to even the most earthshaking events." If anything, the stability predicted by Meyerson and many others was vindicated in the 2004 election where only three states (Iowa, New Hampshire and New Mexico) changed parties. Perhaps, American politics is becoming increasingly geographically stable over time.

Indeed, the myth in this case is not the stability of political geography- political geography is quite stable - but rather that this stability is new or unusual. Figure 3 shows two measures of electoral stability over the last 150 years. The top line shows the correlation coefficient across counties between the percent supporting the Republican Party in the current election and the percent supporting the Republican Party in the previous election. The bottom line shows the share of electoral votes that changed parties since the last election. ${ }^{4}$

The top line shows just how stable political geography has been over the last 130 years. Between 1880 and today there has only been one period where the correlation between current and lagged percentage of Republican voters dropped significantly below 80 percent. In 1964, 1968 and 1972, the coefficient dropped wildly as the South left the Democratic Party. In historical context, this period is unusual, not the 24 years since.

\footnotetext{
${ }^{4}$ In both cases, as in Figure $7 \& 8$ below, we deviate slightly from our usual methodology in our treatment of the 1912 election. In that year, we treat Theodore Roosevelt's progressive supporters as Republicans. Since Roosevelt was a former Republican president, albeit running for election on the Progressive ticket, his supporters do not reflect any real change in support for the Republican party, but rather a temporary deviation to supporting a Republican political idol. Without this correction, the 1912 election would display a particularly unusual degree of political fluidity as Republicans flocked to Roosevelt in 1912 and then flocked back to the Republican fold in 1916.
} 
The correlation between the percentage of voters supporting George W. Bush in 2004 and the percentage of voters supporting Bush in 2000 at the county level is over 95 percent. This is high, but not unlike the degree of electoral stability engendered in the re-election campaigns of Eisenhower or Franklin Roosevelt. In these cases, the correlation coefficients were also in the mid-90s. Over the past 20 years, smoothing out election-byelection variation, the correlation has been lower than during 1932-1960 or 1868-1908. Stability has been the norm, not the exception, in American electoral history, and recent trends have brought us back to this norm.

\section{Myth \# 4: America's cultural divisions are increasing}

A steady stream of rhetoric proclaims that "there is a religious war going on in this country, a cultural war as critical to the kind of nation we shall be as the Cold War itself, for this war is for the soul of America" (this example is from Davis and Robinson, 1997). Fiorina, Abrams, and Pope (2004) provide a rich set of examples showing that across a wide range of issues, the distribution of preferences is single-peaked: most people are in the middle of the distribution and not at the extreme. We will later disagree with Fiorina, Abrams, and Pope (2004) in our interpretation of American political geography, as we believe that there are significant cultural divisions across space and people: Mississippi is not Massachusetts. But we do not disagree with their evidence that divisions across people and space have not been increasing over time.

For example, consider polling evidence on extreme views about abortion. From 1972 to 2004, the share of the population taking the position that abortion should never be permitted has varied in a narrow band between 10-13 percent, according to data from the National Election Surveys. Conversely, the fraction of the population taking the position that abortion should never be forbidden or that a women should always be able to obtain an abortion (the precise wording of the question varied over time) rose from 25 percent in the 1970 s to roughly 35 percent in the 1980s, before peaking at about 45 percent in 1992 and declining back to the 1980s levels since then. Overall, any purported increase in abortion extremism amounts to essentially no change in the share of the population who 
is extremely opposed to abortion and the share of those who believe abortion should never be forbidden fluctuating somewhat, but currently standing at the same level as the 1980s. Similarly, while many Americans are opposed to homosexuality, on the whole, Americans have become significantly more tolerant of homosexuality now then they were 20 years ago. We are not living in an era of increasing cultural divisions between people, even if politicians are increasingly dividing on these issues.

\section{Myth \# 5: America's political divisions are increasing}

A final myth is that we live in an era of increasingly polarized politics, where individuals from different parties increasingly despise one another, or as Lawrence (2002) writes, "when George W. Bush took office, half the country cheered and the other half seethed." Certainly, the heat of the last election, where Democrats accused the President of trading blood for oil, and the Swift Boat Veterans for Truth attacked John Kerry's war record, does suggest rising tempers and mutual distaste.

One usual political science measure of inter-party dislike is the group "thermometer." In "thermometer" questions, respondents are asked to give their feelings towards a group on a 0 to 100 scale with 100 indicating the most positive and 0 indicating the most negative. The National Election Survey offers thermometer ratings towards the Democratic Party and the Republican Party bi-annually since 1978 (with the exception of the 2002 survey, which did not include this question). For the whole period, Democrats' thermometer rating of the Democratic Party averages 73, and their average rating of the Republican Party averages 42 . Republicans, on the other hand, rate the Republican Party at an average of 70 and the Democratic Party at an average of 44 .

Since these ratings may be influenced both by general attitudes towards politics and by partisanship, we compute each individual's relative taste for the Democratic Party by subtracting the thermometer rating towards the Republican Party from the thermometer rating for the Democratic Party. We then average this relative preference for the Democratic Party among Democrats and Republicans separately. 
Figure 4 shows the average relative preference for the Democratic Party among Democrats and Republicans since 1978. The difference between these two lines should be seen as widening partisan hostility. Throughout most of the past 30 years partisanship has been essentially stable, albeit with a slight upwards trend. There was a slight increase in hostility in the early Reagan years and some swings during George H.W. Bush's presidency, but from 1982-1998 partisanship is essentially flat. Moreover, between 1978 and 1998 any rise in partisanship is statistically insignificant.

After 1998 (and particularly between 2000 and 2004), there have been sharp increases in both Republican and Democratic partisanship. Republican enthusiasm for the Republican Party is higher than it has ever been. Democratic hostility for the Republican Party is higher than it has ever been. As such, there is certainly some truth to the view that we are currently experiencing a strongly partisan period, but this does not appear to represent any sort of a secular trend. This division really began in 2000 and seems to be more of a George W. Bush effect than any ongoing move towards greater partisan hostility. Of course, it remains to be seen if partisanship declines in the post-Bush era.

\section{The First Reality of American Political Geography: Cultural Heterogeneity}

These myths have led some observers to suggest that there is no truth to the "Culture War" metaphor or that the red state/blue state division is just plain false. While there are misleading elements of these frameworks, amidst all myths, these ideas also contain two great, essential truths. First, America is a nation of enormous cultural and economic diversity. This diversity is not new and it shouldn't be news, but it is still the central fact of American cultural geography. We earn, consume and believe wildly different things in different parts of this country. To an economist, perhaps the most striking thing is that beliefs can differ so much over space.

Second, American political parties have increasingly become organized around cultural and religious fissures. 30 years ago, income was a better predictor of party than religious 
attendance. Today, religion rather than earnings predicts Republicanism. The rise of religious politics is not without precedent. Prior to 1930, the correlation between religion and party affiliation across states seems to have been at least as strong as it is today. Nonetheless, this cultural division is a central political fact of the last 25 years.

\section{Heterogeneity of Economics and Society}

Using the Pew Research Center's 1987-2003 Values Survey (combined dataset), we have calculated state average responses for a number of questions about values and beliefs. Even pooling over this 16 year time period, sample sizes are often modest, so we include only those states with more than 50 observations over the entire time period. In Table 1, we report the ten most extreme states (including the District of Columbia) for six of these questions. We also include the ten most extreme states in terms of median household income and wine sales per capita. ${ }^{5}$ Since correlations across variables are far less than one, if we followed Ansolabehere, Rodden and Snyder (2006) and look at an average variable to classify states views as unidimensional, we would miss significant amounts of the striking variation that exists across states.

The first panel shows the state average response rate to the question "Should schools fire homosexual teachers?" Across the entire sample, 42 percent answered yes to this question. There is striking geographic variation to this question. In the five most liberal states (with respect to this statement): New Jersey, Maryland, Connecticut, the District of Columbia and Massachusetts, less than 30 percent of respondents thought that teachers should be fired for being gay. In the five most conservative states: West Virginia, Oklahoma, Tennessee, Arkansas and Mississippi, a healthy majority favored firing homosexual teachers. Indeed, almost two-thirds of Mississippi respondents favored

\footnotetext{
${ }^{5}$ One potential issue with a table of this nature is that these samples are not huge and we should expect to see significant variation. However, the variation across states is much higher than we would expect from random sampling error. On average, each state has 440 respondents, and if the true response probabilities were the same across states, we would expect the standard deviation of state level averages to be .023 . The standard deviation of the state means is more than four times this amount. We can soundly reject the view that differences across states just reflect sampling error.
} 
firing such teachers. The standard deviation of state mean is more than four times the standard deviation of state means that would be expected from random sampling error.

The second and third panels show similar geographic heterogeneity in the responses to the statements "It is okay for blacks and whites to date" and "AIDS is God's punishment for immoral sexual behavior." While the extreme left and ring wing states as defined by these first three questions are not the same, the correlations among them are quite high. e.g., the correlation between the belief that schools should fire homosexual teachers and approval of black-white dating is -77 percent.

Figure 5 shows that responses to these cultural statements are highly correlated across states with voting Democratic in the last election. In no state that went for Kerry did the share of respondents agreeing with the statement "AIDS is God's punishment for immoral sexual behavior" exceed 38 percent. In no state that went for Bush did the share of respondents answering no to this question fall below 28 percent. The overall correlation coefficient across states between this variable and voting is -70 percent. The figure also illustrates that there is a continuous distribution of beliefs over space, not two nations. The variation is striking, but the distribution is not bi-modal.

The fourth and fifth panels show that geographic heterogeneity in political beliefs is not limited to cultural issues, but it extends into foreign and economic policies as well. These panels indicate the share of respondents that agree with the statements "the best way to ensure peace is through military strength" and "when something is run by the government, it is usually inefficient and wasteful." The differences in the fraction who agree with these statements between the most liberal and conservatives states are 30-40 percent. Again, America is not two nations, but it does have a lot of geographic heterogeneity in its beliefs.

The heterogeneity of political beliefs is accompanied by striking geographic heterogeneity in religious beliefs. The Pew data have only a limited number of questions 
on religious beliefs, such as "I never doubt the existence of God," and "Prayer is an important part of my daily life." There is geographic variation in the former question: 30 percent of Delaware respondents admit to doubt, while only four percent of South Carolina respondents admit to doubt. There is even more geographic variation in the question on prayer. In this case the range is from 58 percent in Rhode Island to 95 percent in Mississippi.

Other data sets, such as the National Election Survey and the General Social Survey, provide other, perhaps more interesting questions. For example, the National Election Survey provides us with variation in belief about the literal truth of the Bible. In this case, the most believing states were Louisiana and Alabama, where 75 and 69 percent of respondents respectively believed in the literal truth of the bible. The least two believing states were Massachusetts and Connecticut, where only 17 and 20 percent of respondents respectively believed in the literal truth of the bible. The General Social Survey provides us with belief in the existence of the devil. The General Social Survey sample is too small to make comparisons across states, but across regions the variation is significant. In the Pacific region, 49 percent of respondents say that they believe in the devil; in the East South Central region, 82 percent of respondents say that they believe in the devil. ${ }^{6}$

Panel 6 of Table 1, reports the extreme states measured in terms of responses to the statement, "We will all be called before God on Judgment Day to answer for our sins." The five states with the smallest fractions believing in Judgment Day are Vermont, Rhode Island, Oregon, New Hampshire and Nevada. The five states with the highest fractions are Tennessee, South Carolina, Oklahoma, Alabama and Mississippi. These numbers make it clear why a New England agnostic intellectual might indeed feel that the Deep South is another planet. After all nearly 95 percent of respondents from that state will have a fundamentally different view of God and the after-life from this New England agnostic.

\footnotetext{
${ }^{6}$ The Pacific region consists of Washington, Oregon, California, Alaska, and Hawaii. The East South Central region consists of Kentucky, Tennessee, Alabama, and Mississippi.
} 
The regional patterns on moral issues appear to be remarkably durable. Today, the New England and Mid-Atlantic regions are today America's most liberal regions (along with the Pacific Coast). These regions appear to have had liberal views as early as the 1930s. In 1936-37 Gallup polls, across the U.S., 67 percent of respondents said that they would vote for a qualified Catholic for President and 49 percent of respondents said that they would vote for a quality Jew for President. In New England and the Mid-Atlantic region, 74 and 79 percent of respondents said that they would support a qualified Catholic and 62 and 59 percent of respondents said that they would support a qualified Jew, which made these two regions the most tolerant in the county along these dimensions. They were also the most liberal regions in favoring support for federal funding of venereal disease, supporting a free press and opposing the sterilization of criminals. Importantly, in those days, New England had the most conservative views on economic policy.

One of the peculiarities of American geography is that ardent Christianity and belief in the military tend to go together. Across states, the correlation between the share of respondents who say that prayer is an important part of my daily life and the share of respondents who say that the best way to ensure peace is through military strength is 73 percent. One can certainly interpret the Gospels as having an anti-military message, but this doesn't seem to be the interpretation favored by America's most active Christians.

The country doesn't just display remarkable difference in beliefs about religious things like the devil; beliefs about foreign policy related facts also differ significantly across space. For example, a CBS/New York Times poll of April 2004 asked respondents, "Do you think Sadam Hussein was personally involved in the September 11, 2001, terrorist attacks on the World Trade Center?" 45 percent of the South Central region respondents said yes to this question, but only 25 percent of the Pacific Southwest respondents shared this belief. In the same poll, 60 percent of the South Central region respondents and 62 percent of the Mountains and Plains respondents said that they think that "Iraq probably does have weapons of mass destruction that the United States has not found yet?" Only 
forty-three percent of the Pacific Southwest and forty percent of the Pacific Northwest respondents shared this view. ${ }^{7}$

These differences in beliefs within the U.S. drive home one central point about human cognition: the Bayesian approach to learning offers little hope for understanding the remarkable heterogeneity in beliefs across individuals and space (Glaeser 2004). In these rational models, disagreement is difficult, let alone the wild level of dispersion of beliefs that we see. After all, there is no real difference in the evidence that these different states have been exposed to, yet they have come to radically different conclusions, and continue to hold these conclusions despite being aware that others disagree. Despite Aumann (1976), Americans wholeheartedly agree-to-disagree. One natural alternative model is that people base opinions mostly on the views of those around them. As such, local interactions are critical, and these provide plenty of possibility for wide geographic variation (as in Glaeser, Sacerdote and Scheinkman, 1996).

Of course, the nation is different in many other ways as well. According to 2003 Census Bureau figures, the five wealthiest states (Minnesota, Virginia, Connecticut, New Hampshire and New Jersey) had median family incomes around $\$ 55,000$. Mississippi, Arkansas, West Virginia and Louisiana all have median family incomes that are $\$ 20,000$ less than this amount. Of course, these are nominal income levels, uncorrected for state cost of living, but certainly the ability to buy traded goods is far lower in these poorer states. Unsurprisingly, there is a healthy correlation between attitudes and income. The correlation between mean income and acceptance of black-white dating is 58 percent. The correlation between income and the belief that homosexual teachers should be fired is -68 percent. A particularly surprising relationship is the fact that the correlation between state median income and share of respondents that say that poor people have become too dependent on government assistance is -38 percent. As we will discuss later,

\footnotetext{
${ }^{7}$ The Pacific Southwest includes California, Nevada, Arizona, and Hawaii. The Pacific Northwest includes Alaska, Washington, Oregon, and Idaho. The South Central includes Texas, Oklahoma, Arkansas, Louisiana, and New Mexico. The Mountains and Plains include Colorado, Utah, Wyoming, Montana, North Dakota, and South Dakota.
} 
the fact that respondents in poorer states are more likely to have anti-redistribution opinions makes us doubt whether these opinions should be seen as being exogenous variables that reflect true economic interests. Another quite plausible view is that these opinions are the result of political affiliation and the desire to be consistent with the party line.

While there is a positive correlation between voting Republican and the share of respondents that say that poor people have become too dependent on government, the correlation between state income and Republicanism is -43 percent. Since individual level income still positively predicts voting Republican (albeit weakly), the negative correlation between income and Republicanism at the state level represents one of those interesting instances in which aggregate relationships are the reverse of individual relationships (as in Glaeser and Sacerdote, 2001). This relationship, however, disappears if we control for state level cultural variables or even urbanization, and one explanation for this phenomenon is that the correlation between income and culture is much stronger at the state level than at the individual level.

Differences in consumption patterns are even greater than differences in income. The five states with the least wine sales (West Virginia, Mississippi, Oklahoma, Arkansas and Iowa) sold around 1 gallon of wine per capita in 2002. The five areas with the most wine sales (Massachusetts, Nevada, Idaho, New Hampshire and the District of Columbia) consumed nearly five times as much wine per capita. Even wine consumption is correlated with political and social beliefs, often in surprising ways. For example, the correlation between wine consumption and the share of respondents who think that blackwhite dating is okay is 61 percent.

While the geographic differences within America are large, they are not new and they do not seem to be growing. There is little evidence to back up E. J. Dionne's assertion that red states are getting redder and blue states are getting bluer. We compared the variance of state averages during the 1987-1993 period and the 1994-2004 period. The variance across states in the opinion that schools should fire homosexual teachers has risen 
slightly. The variance of the state average view that it is okay for blacks and whites to date has fallen more. The variance of the view that AIDS is God's punishment has risen. The variance in the share of the population that takes the Bible to be the literal word of God has fallen. The variance of the share that thinks that the government is often inefficient and wasteful has risen. Overall, it is hard to see a general trend. The nation is different and it has been so for many years.

\section{The Causes of American Cultural Diversity}

While the differences in political and social beliefs across space are striking and while many of these correlations are provocative, these correlations give us little idea about what factors explain differences in beliefs across the United States. In this section, we consider three possible explanations: long-standing differences in religious adherence across states, the legacy of slavery, and diversity in the marketplace. The first hypothesis suggests that the fundamental difference between areas within the U.S. is simply the degree of religiosity. The second hypothesis is that regional differences fundamentally reflect the legacy of slavery and the Civil War.

The third hypothesis - diversity in marketplace-- suggests that areas where diverse populations interacted in market settings developed beliefs that reduced ethnic and religious conflict. According to this view, if ethnic groups interact at high densities, they either destroy each other or eventually develop ideologies that minimize conflict. ${ }^{8}$ While many of the "liberal" responses to survey questions suggest tolerance towards minorities or people who violate traditional religious norms, this hypothesis does not imply that blue state America is tolerant and Red State America is not. Blue State America is more intolerant of some groups like the religious and Southerners. Instead, this hypothesis suggests that Blue State ideology is tolerant in ways that reduced the ethnic and religious conflicts that could have hurt an economy depending on ethnically diverse populations working together at high densities.

\footnotetext{
${ }^{8}$ Alternatively, the hypothesis can be interpreted as suggesting a reverse causality where diverse ethnic groups economically interact only in places that have managed to reduce conflict.
} 
To measure the historical religious environment, we use the 1926 Census of Religious Bodies which provides a count of members of different churches at both the county and state level. Because some denominations (Catholics, Lutherans, Episcopalians) include children in their membership, but most other Protestant denominations do not (or do not do so consistently), we follow Johnson, et al (1974) and multiply membership in churches which substantially underreport child participation by the total county population divided by the population over 14. Then, using the classification groupings of the American Religion Data Archive (www.thearda.com) based on the research of Steensland, et al (2000), Melton (1999) and Mead (1995), we calculate the number of church members who are evangelical. ${ }^{9}$ The county-level correlation between adherents per capita in 1926 and adherents per capita in 1990 is $.44 .{ }^{10}$ We present the results for evangelicalism because it is both more correlated over time and more correlated with modern religious behavior

To test whether current political divisions reflect the enduring legacy of slavery and the Civil War, we use the number of slaves per capita in the state in 1850 . For places that weren't states, this variable takes on a value of zero. Because this variable is highly skewed, we use the logarithm of one plus this variable (none of our results change if we use the linear specification). Our results are also unchanged if we replace this continuous variable with a discrete variable that takes on a value of one if the state was a member of the Confederacy.

The diversity hypothesis is tested using three different measures of diverse social environments. First, using Census data we use the share of the population that is foreign born in 1920. We have reproduced our results using a fractionalization index of ethnic heterogeneity based on country of birth in the 1920 Census. ${ }^{11}$ Second, we use the share

\footnotetext{
${ }^{9}$ For a complete description of how the modern list was matched to historical denominations, see the data appendix posted at http://www.people.fas.harvard.edu/ bward

${ }^{10}$ We exclude 5 counties with adherents per capita well above 1 in 1926 from this correlation.

11 The results with ethnic-fractionalization indicies which include race as well as foreign-born ancestry change the results discussed below slightly. Specifically, the significance the slavery measure increases slightly for several of the outcomes, and the significance of the log of density decreases slightly.
} 
of the population that worked in manufacturing in 1920. This variable is highly correlated with the density and urbanization of an area, and we see it as a proxy for high density economic interactions. We have obtained similar results using the share of the population in 1920 that lives in cities with more than 25,000 people.

Regressions (1)-(6) show our results for states and regression (7) shows the connection between these explanatory variables and the share voting for Kerry at the county level. In the state level regressions, the explanatory power is quite high and r-squareds run from 48 percent to 70 percent. In the county level regressions, the r-squared is 14 percent.

The first row shows the impact of evangelism in 1926. Evangelicalism in 1926 is statistically significant in four out of seven specifications. For example, it significantly predicts approval of black-white dating and belief in peace through strength, and it weakly predicts the belief that AIDS is a punishment from God and the importance of prayer. In most cases, the coefficients are reasonably large, but due to the high correlation of the independent variables, this variable is not highly significant. In univariate regressions, the evangelicalism variable is almost always significant.

In the second row, we see the coefficients on the slave population in 1850. In this case, the coefficients are typically small and quite insignificant. The same is true of the categorical variable depicting membership in the confederacy. There are two variables which this variable (or the confederacy variable) is correlated with - the belief in peace through strength and, somewhat surprisingly, a belief in the efficiency of government. These effects, while significant, are still quite small. While it is not impossible that the legacy of slavery matters, there is no sense that support for Republicanism is determined by the borders of the old slave states, and despite E. J. Dionne's views, there is little evidence to suggest that current political and social divisions reflect the ongoing legacy of the Civil War.

In the third row, we look at the importance of percent foreign born in 1920. In this case, the coefficients are generally significant economically and statistically. As the share of 
the state that is foreign born in 1920 increases by one percentage point, the share of respondents who say that AIDS is God's punishment declines by .271 percent point and the share of respondents who say that homosexual teachers should be fired declines by .504 percentage points. Foreign born is also negatively associated with the importance of prayer and positively correlated with acceptance of interracial dating. Finally, this variable is strongly positively associated with support for the Democratic Party. As the county share foreign born in 1920 increases by one percentage point, the share supporting Kerry increases by almost one-half of a percentage point.

The fourth row examines the impact of the share of the workforce in manufacturing in 1920. In this case, the coefficients are significant in every regression except on blackwhite dating. Industrialization 85 years ago is an astonishingly good predictor of social and cultural attitudes today across states and a good predictor of support for the Democratic Party at both the state and county levels. As the share of the workforce in 1920 in manufacturing increases by one percentage point, the share of respondents today believing that AIDS is punishment declines by 28 percentage points, the share believing that military strength is the best way to peace declines by .16 percentage points, and the share supporting John Kerry at the state level increased by .42 percentage points.

Religious and political attitudes are better predicted by industrialization and immigration 100 years ago, then by the history of slavery and religion. Traditional religious views and voting Republican is strongly associated with places where Anglo-Americans lived with fewer immigrants. Likewise, late industrialization is also strongly associated with Republican ballots and views that are now Republican. History does matter, but it seems that cultural and political divides have at least as much to do with industrialization and immigration than with religious history or slavery.

While there are many possible explanations for the connection between immigration, industrialization and culture, one hypothesis is that diverse populations working together at high densities, eventually develop ideologies that minimize conflict. Alternatively, areas that were more productive and that sought new immigrant labor encouraged views 
that minimized religious strife and encouraged financially profitable immigrants. New York City has a remarkable history of religious tolerance dating from its founding as a commercial colony. Its Dutch commercial leaders tolerated Jews and heterodox Christians because their presence would increase the economic welfare of the colony. Through the early $20^{\text {th }}$ century, industrialists generally opposed the intolerant, nativist strain that would eventually shut off the supply of cheap immigrant labor.

New England's path to religious tolerance also shows the importance of commerce and heterogeneity. . Early seventeenth century Massachusetts is usually put forward as a model of intolerance, not openness, and Protestants of differing views were exiled (like Anne Hutchison) or killed (like Quakers). However, by the 19th century, tolerant Unitarianism had replaced strict Congregationalism, and as we have already discussed in the first decades of the $20^{\text {th }}$ century, New England was remarkably socially liberal.

The change appears to have begun even at the end of the eighteenth century, as "merchants increasingly were dependent on their commerce with the outside world and believed in seeking an accommodation with that world" (Bremer, 1995, p. 173). Between 1690 and 1710, traditional Puritanism declined. The state legislature pushed Increase Mather, a champion of traditional Puritanism, out as President of Harvard. Merchants, like Thomas Brattle, endowed more liberal churches, and, in 1699, the "Brattle Street Manifesto" affirmed a far more tolerant form of Congregationalism. The decline of strict Puritanism appears to have been primarily the result of actions by merchants like Brattle and Elisha Cooke who followed the merchant led community in New York towards a more religiously tolerant and less religious community (the stricter Congregationalists of course founded a competing college in New Haven).

This hypothesis does not mean to suggest that diversity always leads to tolerance. Indeed, in many cases, diversity leads at least initially to hatred and ethnic conflict (Glaeser, 2005). However, if different religious or ethnic groups are prevented from using the power of the state to disenfranchise, enslave or kill each other, and if there 
exists a powerful group that benefits from eliminating conflict, then diversity can eventually lead to a watering down of core religious tenets or ethnic animosities.

\section{The Second Reality of American Political Geography: Politics follows Culture}

Around the 2004 election, many authors commented on the remarkable correlation between the tendency to go to church and the tendency to vote Republican.

The overall correlation between income and Republicanism among white males is essentially zero outside of the extremes of the income distribution (Glaeser, Ponzetto and Shapiro, 2005). However, the relationship between Religion and Republicanism is extremely strong throughout the distribution. Individuals who go to church once a month vote Republican 66 percent of the time; individuals who go to church once per week vote Republican 75 percent of the time. The correlation between the church attendance variable and Republicanism is 20 percent.

This increasing importance of religion does represent a shift over the past 50 years. Figure 7 shows the impact of income and religion over the past 50 years. The vertical axis depicts the OLS coefficients from estimation of the following equation for each election year:

(1) $\operatorname{Pr}\left({\text { Republican })_{\mathrm{i}}=\beta \bullet \ln \left(\text { Income }_{\mathrm{i}}\right)+\delta \bullet \text { church attendence }}_{\mathrm{i}}+\mathrm{X}_{\mathrm{i}}{ }^{\prime} \varphi+\varepsilon_{i}\right.$,

where $\operatorname{Pr}($ Republican) is a categorical variable taking on a value of one if the individual votes republican, $\ln \left(\right.$ Income $\left._{i}\right)$ is the logarithm of family income, church attendance is a categorical variable taking on a value of one if the individual attends church once per month or more. The $\mathrm{X}$ vector includes controls for gender, race, education and age. As before, we have excluded voters who chose neither Republicans nor Democrats. The black line shows the effect of log of income, and the grey line the effect of attending church once a month or more. The coding of religion in the National Election Survey changed in 1972, so it is inappropriate to compare the magnitude of effects before that 
date with the magnitudes after then. ${ }^{12}$ The figure suggests that in the 1970 s and before, the coefficients on income and church attendance were comparable. Since 1980, religion has become much more important.

To analyze longer historical patterns in the relationship between income and Republicanism, we turn to county level election returns and during each election from 1864 until today we regress:

$$
\frac{\text { Republican Votes }}{\text { Total Votes }}=\alpha+\beta \bullet \log (\text { Median Income in } 1950)+\varepsilon
$$

where $\alpha$ is a constant and $\beta$ captures the relationship between Republicanism and income. We use income in 1950 because income is not available before 1947 and we wanted to be able to use a consistent measure of county wealth. Results look similar if we use the logarithm of contemporary income for the post-1950 period. Because of the correlation between income and the South, we also present estimates of $\beta$ in regressions that include a dummy variable indicating that the state was a member of the Confederacy and in regressions excluding all of those states.

The top line shows the estimates from a regression with no Confederacy control and that regression shows a straightforward rise and decline in the connection between income and Republicanism. The most basic fact is that from the 1870 s to the $1950 \mathrm{~s}$, richer states were reliably more Republican and this is no longer true today. On average, a one log point increase in 1950 median income (roughly a doubling) generally increased the share of the population that voted Republican by 4 percent between 1868 and 1956. The bottom line excludes the south, and in this case, there is a very long term pattern (18702004) and a recent pattern (1976-2004) of declining correlations between income and Republicanism, but over in the middle part of the $20^{\text {th }}$ century, there is extreme volatility

\footnotetext{
${ }^{12}$ Prior to 1972 , the church dummy is equal to one if the respondent attends church often or regularly. The fraction of respondents in these categories in 1968 (the last year it was phrased in this way) is basically the same as the fraction attending church at least once a month in 1970 (the first year of the new version).
} 
in the income-Republicanism relationship mostly associated with the ability of Democrats to attract high income urban counties. Finally, the middle line shows an even more complex pattern, but one that still supports a declining relationship between income and voting Republican at the county level.

Our results contrast with those presented by Ansolabehere, Rodden and Snyder (2006) who argue that economics remains a more important predictor of political orientation than morals. Our results differ because they use opinions on issues to predict voting and we use actual income and religious attendance. Income doesn't strongly predict voting Republican but their economic issues index does. On moral issues both opinions and harder variables like church attendance predict Republicanism.

To believe Ansolabehere, Rodden and Snyder's (2006) view that economic issues continue to trump moral issues, you must believe that the importance of economic voting should be measured by using opinion surveys about economics rather than actual income. If these survey opinions are the result of political affiliation rather than the cause (either because of social persuasion as in Murphy and Shleifer, 2004, or because of a desire for internal consistency), then it would make little sense to regress voting on opinions. The first reason to question the use of these surveys is that responses are weakly correlated with individual economic status and correlations at the state level generally go in the wrong direction. Economic opinions don't appear to respond to economic interests.

A second issue with the Ansolabehere, Rodden and Snyder (2006) economic issues index is that this index is the result of factor analysis designed to find opinions that tend to go together. The opinions that go together and are labeled "economic issues" are an odd mix including enthusiasm for government spending, environmentalism, health insurance and labor unions. These views have little in common other than being major parts of the Democratic platform, and one plausible interpretation of the factor analysis is that instead of finding exogenous preferences for economic policy, they have identified the common factor that is ideological loyalty to the Democratic Party. 
A third reason to be suspicious of economic opinions is the pattern of regional change, especially relative to the persistence of moral opinions (New England was liberal on religious issues in the 1930s and remains so today). In the 1930s, Republican New England was anti-government and pro-free market and the Democratic South was strongly pro-redistribution. These opinions have completely flipped as party affiliations have flipped. There is no sense that the changing patterns reflect changing economic fortunes, because after all, these opinions remain negatively correlated with economic realities. As such, we think that it is more sensible to look at hard variables that capture economics and religion, like income and church attendance, and these variables show a steady increase in the correlation between religiosity and Republicanism relative to the constant correlation or declining correlation between Republicanism and income.

If the correlations between economics and Republicanism are open to debate, there is little doubt the religiosity increasingly predicts voting Republican. This voting pattern is is mirrored by changes in party policies and party platforms. Glaeser, Ponzetto and Shapiro (2005) compare the party platforms of Republicans and Democrats in 1976 and 2004. During the earlier time period, the Democratic platform took a truly moderate stance, recognizing the differing views of many Americans, but finding it "undesirable to attempt to amend the U.S. constitution to overturn the Supreme Court decision in this area." In that platform, the Democratic platform supported "the Congressional efforts to restrict the use of taxpayers' dollars for abortion." In 2004, far from considering a prolife Amendment, the Democratic Party stood “proudly for a women's right to choose, consistent with Roe v. Wade, and regardless of her ability to pay." The Republican platform similarly trended right and in 2004 stated that "the unborn child has a fundamental individual right to life that cannot be infringed." Interestingly, political rhetoric was matched with little visible action; there is no difference in the number of abortions per capita under Democratic and Republican presidencies (Glaeser, Ponzetto and Shapiro, 2005).

The abortion gap between the parties is mirrored by gaps in many religious or cultural policies. The Republican platform also opposes gay marriage and embryonic stem cell 
research. Democrats have clearly taken opposing positions on these and similar issues. By contrast, in the debate over the Iraq war, John Kerry claimed to differ primarily in his competence and ability to bring in allies, not in his commitment to fighting America's enemies. In the economic sphere, both party platforms trumpet their commitment to reducing taxes (Glaeser, Ponzetto and Shapiro, 2005). The starkest differences in both public statements of candidates and in the wording of the platforms occur along moral dimensions. Given the statements of party platforms, it is no surprise then that religion predicts party preference better than income.

The recent rise in the connection between politics and religion hardly represents something new in American politics. In the pre-modern era, religion was also a central part of party politics. . Party platforms during the nineteenth century also often contained significant religious or cultural statements. For example in 1880, the Republican Party platform attacked Catholic education by endorsing a constitutional amendment "to forbid the appropriation of public funds to the support of sectarian schools." In 1884, the platform resolved "that it is the duty of Congress to enact such laws as shall promptly and effectually suppress the system of polygamy within our Territories; and divorce the political from the ecclesiastical power of the so-called Mormon Church." In 1888, the platform contained a moderate pro-prohibition plank supporting "all wise and welldirected efforts for the promotion of temperance and morality." Fifty years later, the Democratic platform called for a repeal of prohibition.

The relatively mild language of the platforms was coupled with stump speeches which emphasized cultural or religious divisions. Following Samuel Burchard in 1884, Republicans accused Democrats of standing for "Rum, Romanism and Rebellion." By contrast, the Democrats relied upon their urban support from Catholic immigrants from Ireland and Germany. Indeed, the roots of the Republican Party are in the religioninspired battle against slavery. Protestant ministers like Henry Ward Beecher (whose sister wrote Uncle Tom's Cabin) fervently supported the Republican Party before the Civil War. 
However, while these anecdotes certainly suggest that it was possible that religion mattered as much in the past as it does today, it provides us with no quantitative evidence on this topic. To analyze historical patterns, we turn to county level election returns and during each election from 1864 until today we regress:

$$
\frac{\text { Republican Votes }}{\text { Total Votes }}=\alpha+\beta \bullet \frac{\text { Adherents in a Set of Denominations }}{\text { Total Church Adherents }}+\varepsilon
$$

where $\alpha$ is a constant and $\beta$ now captures the relationship between Republicanism and religious affiliation. In this case, we present results with and without the variable capturing membership in the Confederacy. We use two different religion variables: the share of church members that are evangelicals and the share of church members that are mainline Protestants. Catholics represent the main excluded category. We use religious censuses from 1890, 1926, 1952 and 1990, and in all cases, we used the data from the chronologically closest religious census. Given the extremely high persistence of denomination over time (the 80+ percent correlation between evangelicalism in 1926 and 1990), these results are not particularly sensitive to using religion measures from other years. Mainline Protestants primarily include Presbyterians, Episcopalians, Lutherans, and Methodists, while evangelicals are more conservative and include a wide array of groups like Southern Baptists and Pentecostals. ${ }^{13}$ Again, we use the American Religion Data Archive (www.thearda.com) classification.

Figure 8 shows our results where the data is smoothed by averaging the estimates of $\beta$ over three elections and graphing the results. We again treat votes for Theodore Roosevelt in 1912 as votes for the Republican Party in that year. There are obviously many different ways of performing this exercise, but this provides a simple sense of the

\footnotetext{
${ }^{13}$ Steensland, et al (2000) provide a basic description of the major differences between Mainlines and Evangelicals: "Mainline denominations have typically emphasized an accommodating stance toward modernity, a proactive view on issues of social and economic justice, and pluralism in their tolerance of varied individual beliefs. Evangelical denominations have typically sought more separation from the broader culture, emphasized missionary activity and individual conversion, and taught strict adherence to particular religious doctrines."
} 
correlates of Republicanism, at least at the county level, in the time period before opinion polling.

The bottom line charts the changing relationship between the Republican Party and evangelicals. During the early time period, even controlling for being a Southern county, evangelical counties were much more likely to be Democratic than to be Republican. Over the last 25 years that has changed, and today there is a significant positive relationship between the share of the religious population that is evangelical and the share of the population that voted for George Bush. As the share of the population that is evangelical increases by one percentage point, the share voting Republican increases by .13 percentage points.

But the graph makes it clear that while the connection between Republicanism and evangelicalism may be new, the connection between religion and politics is not. The connection between mainline Protestantism and Republicanism during the late $19^{\text {th }}$ century was much stronger than the correlation between evangelicalism and Republicanism today. Even as late as the Eisenhower era, this connection remained strong. Of course, this correlation is partly a reflection of the strong ties between the Republican Party and the mainstream churches, but it is also a reflection of the equally strong ties between the Democrats and the Catholic Church.

The conclusion from this graph is that religion has usually played a role in party divisions. The patterns have changed. Today attendance is a bigger predictor of voting Republican. In the past, mainline Protestantism predicted Republicanism. In the next section, we turn to explanations of the connection between religion and political divisions.

\section{Explaining Party Divisions}

The traditional problem with explaining why parties divide on some issues rather than others is that the prevailing paradigm in political science has been the median voter 
theorem. This result pushes strongly towards the implication that parties will rush to the center, and if all parties are at the center then there is little possibility of explaining why Republicans and Democrats split on religion rather than economics.

To the extent that there has been an alternative paradigm, it is that the preferences of leaders or elites pull parties away from the median voter. In this case, party leaders sacrifice votes to achieve their own goals, and the implication is that parties will divide on issues that party elites really care about. This theory can potentially explain the division on religion. It wouldn't be surprising if party leaders had stronger preferences for religion-related issues than for tax policy, especially if they interact in social organizations that emphasize religion (Murphy and Shleifer, 2004). Indeed, it is quite possible that this does explain part of the tendency of parties to split on these cultural issues: this is what party leaders do seem to care most about.

Unfortunately, this theory gives us little guidance about why the connection between religion and party affiliation has changed over time, or why the connection between religion and party affiliation is different in different countries. Glaeser, Ponzetto and Shapiro (2005) show that in some countries (like India) religion correlates strongly with political affiliation but income does not. In other countries (like Sweden), income correlates strongly with political affiliation but religion does not. And in some places (like Spain) both income and religion correlate quite strongly with political affiliation. These differences can't be explained by a general tendency of leaders to care more about social issues.

To explain these differences over space and time, Glaeser, Ponzetto and Shapiro (2005) present a model of strategic extremism where parties divide on issues not to appease the tastes of the leaders but rather to increase their chances of electoral success. As Downs (1957) intuited and Riker and Ordeshook (1973) proved, extremism (defined as party policies that differ from those of the marginal voter) hinge on a turnout margin. If everyone always votes, then moving away from the center is always costly for politicians trying to get elected. Extremism can become strategic, i.e. vote enhancing, only when 
there is a turnout margin so that by moving from the center, you excite your base and get them to come to the voting booths. ${ }^{14}$

However, a turnout margin is not enough to ensure extremism. Even with a turnout margin, going to extremes has, in principle, equal likelihood of exciting your base and exciting your opponent's base in the opposite direction. As a result, a voting margin is not enough. There must also be an asymmetry so that extremism excites your supporters more than it enrages your opponent's supporters. Glaeser, Ponzetto and Shapiro (2005) suggest a natural source of this asymmetry: the ability to target messages towards one's own supporters. If your supporters hear your messages (speeches, platforms, etc.) more than your opponents, then going to extremes will increase support more than it increases opposition. In the model, the opposition support is not fooled: they correctly anticipate what you will be saying. Nonetheless, there is still an asymmetry, because if you don't take an extreme position then your own supporters will know that you are centrist and will fail to vote.

This model suggests that policy divisions will be closely tied to the ability to send coded messages (this was called Dog Whistle Politics in the latest British parliamentary race). Large social organizations, like churches or unions, can provide politicians with just this ability. Inside a religious services or a labor meeting, outsiders are absent, and there is an ability to send targeted messages. There are of course abundant examples from Henry Ward Beecher to Pat Robertson of Churches being used to send political messages. It is also certainly true that labor unions have historically provided a key venue for dissemination of political positions.

The model suggests, somewhat surprisingly, that the influence of a social group is nonmonotonic and it peaks when the group represents slightly less than one-half of the population. The intuition of this is that when the group represents the entire population, it no longer provides an opportunity to target messages, and when the group represents no

\footnotetext{
${ }^{14}$ A contribution margin can work just as well. The key is that there is some margin where intensity of support matters.
} 
one, it is no longer an important political force. When the group is slightly less than onehalf of the population, then its key issues (economics in the case of unions and social issues in the case of churches) will come to dominate political division and debate.

One particularly clear example of how social groups determine policy divisions is the role of the Grand Army of the Republic (GAR) in the rise of the Grand Old Party. The GAR, a vast veteran's group from the Civil War, provided the Republican Party with a natural means of sending targeted messages reminding voters of Democrat's activities in the civil war ("not every Democrat was a rebel, but every rebel was a Democrat") and pledging future Republican policies towards veterans and freed slaves. This access ensured that Democrats and Republicans would continue to divide on Civil War related issues for 50 years after the war.

This theory then provides us with two hypotheses for the changing importance of economic and social issues in American politics and for the realignments throughout the $20^{\text {th }}$ century. One candidate is the rise and fall of unionization in America. At the beginning of the century, unions were a small part of the population. Only in small areas of the population did they provide an opportunity for targeting a significant fraction of the population. In mid-century, they rose to over 30 percent of all workers and today they are back down to 12 percent (Troy 1965, www.laborresearch.org).

The rise and fall of unionization corresponds reasonably with the connection between income and Republicanism shown in Figure 10. The middle decades of the $20^{\text {th }}$ century were the high point of unionism and they were also the high point of the correlation between income and Republicanism. During this time period, the Democratic Party had access to the labor unions and this created an incentive for Democrats to move to the left on economic issues to get support in this important base. The rise and decline of unions provides at least one possible reason why economic issues rose and then fell in importance. 
A second hypothesis explaining the rise and fall of religion is the changes in the religious market. Over the past 80 years, there has been a decline in the numbers of mainline Protestants and a rise in the number of evangelicals. According to this hypothesis, as the mainline Protestants declined in importance, the Republican Party stopped catering to their interests, and gradually switched to issues that were more significant to the growing numbers of evangelicals. Democrats have been more successful at connecting with the rise in non-Christian religious groups (Fogel, 2001).

While this story makes perfect sense from a Republican stand point, it makes less sense for Democrats. Why didn't Democrats move to capture the votes of evangelicals? Certainly, the presidency of Jimmy Carter suggests that this was far from impossible. There are several hypotheses. First, Democratic policies towards civil rights had alienated a huge part of the evangelical population. Second, liberal elites in the Democratic Party were uncomfortable with moving to the right on social issues. Third, the Democrats were dominant during a period of rapid social change and had difficulty running against socially liberal policies that had been enacted and popular during their time in power.

This discussion has emphasized the role of religion as if churches were just another form of social group and as if religious views were no different than views over fiscal policy. But in fact, many people take their religious views far more seriously than views on other topics, and this may also help us to understand why religion is so often an important part of politics. It may be far easier to motivate voters by appealing to core religious values than to topics like tax policy, and this may be the key reason why religion is so appealing to politicians.

Whatever the cause, the trends are clear. While Republicanism used to represent mainline Protestantism, it now represents evangelicalism. The ability to send targeted messages helps us understand why social groups, such as churches or unions, end up driving the key differences between parties. As such, we should neither be surprised at today's religious politics, nor at the politics of religion in the past. As long as churches 
provide politicians with an ability to send targeted messages to supporters, religious issues will be important in elections and parties will divide over religion.

\section{Conclusion}

There are many myths about America's political geography. There has not been any decrease in the number of swing states over time. Democrats and Republicans are no more geographically segregated than they have been in the past. Voting patterns may have become mildly more persistent than in the past, but persistence has usually been quite high, except for the 12 year period when the South left the Democratic fold. Cultural heterogeneity is not increasing and most people are in the middle, not at the extremes (as in Fiorina et al., 2004). Political hostility between the party members is relatively constant, although there has been an uptick in hostility over the last four years.

But all of these myths should not obscure two primary truths about American political geography. First, America is a nation with an astonishing degree of cultural diversity. The Red State/Blue State framework makes it appear that regions fall into one of two groups and this is false. There is a continuum of states ranging from the poor conservative places of the south and west to the rich, liberal places of the coasts. These places are quite different and they have been so for many years. At the state or county level, these differences line up well with political affiliation.

The roots of these geographic differences seem to come from two primary sources: industrialization and immigration. Places that industrialized earlier and that attracted more immigrants at the start of the century are much more likely to have socially liberal attitudes, much less likely to take prayer seriously, and less likely to vote Republican. These forces appear to be much more important in predicting attitudes and politics than the legacy of the Civil War, or long-standing religious differences. One theory that can explain the power of immigration and early industrialization is that the cultural attitudes associated with the Democratic party (downplaying Religion and emphasizing some 
forms of tolerance) reflect the long run effect of ethnically and religiously heterogeneous populations interacting over many decades in the marketplace

The second great truth is that American parties are increasing oriented around religion and culture rather than economics. This change has occurred since the 1970s, but in broader historical perspective it is the 1932-1976 period that is exceptional, not the current epoch. Prior to 1932, religion also predicted voting, but during that era the key correlation was between Republicanism and mainline Protestantism.

Why has religion or culture played such an important role in American party divisions? We offer two explanations. Glaeser, Ponzetto and Shapiro (2005) show that parties divide along issues where they have the ability to send targeted messages to their supporters. Religious groups provide just this ability. Second, voting is innately irrational, and emotional cultural topics may be much more effective in getting people into the voting booth than naked self-interest. 


\section{References}

Ansolabehere, Stephen, Rodden, Jonathan, and James M. Snyder, Jr. "Purple America," Journal of Economic Perspectives, this issue.

R. J. Aumann, “Agreeing to disagree.” Annals of Statistics, 4(6) (1976):1236 - 1239.

Bishop, Bill, "The schism in U.S. politics begins at home." Austin-American Statesman, April 4, 2004.

Bradley, M. B., Green, N. M., Jones, D. E., Lynn, M. \& McNeil, L., Churches and Church Membership in the United States, 1990, (Atlanta: Glenmary Research Center, 1992).

Bremer, Francis J. The Puritan Experiment: New England Society from Bradford to Edwards. (Hanover and London: University Press of New England, 1995).

CBS News/The New York Times. CBS News/New York Times Monthly Poll, April 2004. ICPSR version.(Ann Arbor, MI: ICPSR 2004). Dataset 4101.

Clubb, Jerome M., William H. Flanigan, and Nancy H. Zingale. Electoral Data for Counties in the United States, 1840-1972. (Ann Arbor, MI: ICPSR, 2005). Dataset 8611.

Davis, James A., Tom W. Smith, and Peter V. Marsden, General Social Surveys, 19722002 (Ann Arbor, MI: ICPSR, 2003). Dataset 3728.

Davis, Nancy J., and Robert V. Robinson, “A War for America's Soul: The American Religious Landscape." In Cultural Wars in American Politics: Critical Reviews of a Popular Myth, ed. Rhys H. Williams. (New York: De Gruyter 1997).

Dionne, E.J., “One Nation Deeply Divided.” The Washington Post, November 7, 2003.

Downs, Anthony, "An Economic Theory of Political Action in a Democracy," Journal of Political Economy, 55 (1957), 135-150.

Fiorina, Morris P., "Whatever Happened to the Median Voter?," Stanford University Mimeograph, (1999).

Fiorina, Morris P., Samuel J. Abrams, and Jeremy C. Pope, Culture War? The Myth of a Polarized America (New York, NY: Pearson Longman, 2005).

Fogel, Robert W. The Fourth Great Awakening and the Future of Egalitarianism (Chicago: University of Chicago Press, 2000).

Glaeser, Edward L., Bruce Sacerdote, and Jose Scheinkman, "Crime and Social 
Interactions," Quarterly Journal of Economics 111 (1996): 507-548.

Glaeser, Edward L. and Bruce Sacerdote, "Education and Religion," NBER Working Paper No. 8080, 2001.

Glaeser, Edward L., "Psychology and the Market" American Economic Review Papers and Proceedings 94(2) (2004): 408-413.

Glaeser, Edward L., Giacomo A.M. Ponzetto, and Jesse M. Shapiro, "Strategic Extremism: Why Republicans and Democrats Divide on Religious Values," Quarterly Journal of Economics, forthcoming (2005).

Haines, Michael R., and the Inter-university Consortium for Political and Social Research. Historical, Demographic, Economic, and Social Data: The United States, 1790-2000. (Ann Arbor: MI: ICPSR, 2004). Dataset 2896.

Inter-university Consortium for Political and Social Research. General Election Data for the United States, 1950-1990. (Ann Arbor, MI: ICPSR,1995). Dataset 0013.

Johnson, Douglas W., Picard, Paul R. and Quinn, Bernard Churches and Church Membership in the United States, 1971. (Washington: Glenmary Research Center, 1974).

Klinkner, Philip A., "Red and Blue Scare: The Continuing Diversity of the American Electoral Landscape" The Forum. 2(2) (2004).

Labor Research Association, U.S. Union Membership, 1948-2004. http://www.laborresearch.org/charts.php?id=29 (2004)

Lawrence, Jill, "Behind Its United Front, Nation Divided as Ever," USA Today, February 18, 2002.

Leip, David, Dave Leip's Atlas of U.S. Presidential Elections. http://www.uselectionatlas.org, (2005).

Mead, F. S., as revised by Hill, S. S. Handbook of Denominations in the United States, 10th ed. (Nashville: Abingdon, 1995).

Melton, J. G., Encyclopedia of American Religions, 6th ed. (Detroit: Gale Research, 1999).

Meyerson, Harold, "Democrats in a Divided Land," The Washington Post. November 5, 2004.

Murphy, Kevin M. and Andrei Shleifer, "Persuasion in Politics" American Economic 
Review Papers and Proceedings 94(2) (2004): 435-439.

The National Election Studies, The 2004 National Election Study. (Ann Arbor, MI: University of Michigan, Center for Political Studies, 2004).

National Institute of Health, "U.S. Apparent Consumption of Alcoholic Beverages Based on State Sales, Taxation, or Receipt Data." U.S. Alcohol Epidemiologic Data Reference Manual., Volume 1, Fourth Edition, NIH Publication No. 04-5563, June 2004.

PEW Center for the People and the Press. 1987-2003 Values Survey (combined dataset). (Washington, DC: Pew Center, 2003).

Riker, William H. and Peter C. Ordeshook, An Introduction to Positive Political Theory Prentice-Hall Contemporary Political Theory Series (Englewood Cliffs, NJ: Prentice-Hall, 1973).

Sapiro, Virginia and Steven J. Rosenstone, American National Election Studies Cumulative Data File, Vol. 8475 (Ann Arbor, MI: ICPSR, 2002).

Steensland, B., Park, J. Z., Regnerus, M. D., Robinson, L. D., Wilcox, W. B. \& Woodberry, R. D. "The measure of American religion: Toward improving the state of the art", Social Forces 79 (2000):291-3

Troy, Leo. "Trade Union Membership, 1897-1962," National Bureau of Economic Research Occasional Paper No. 92. (New York: Columbia University Press, 1965). 
Figure 1 -- Popular Vote Margin of Victory and Share of Electoral Votes in Battleground States (10\%) in US Presidential Elections, 1840-2004

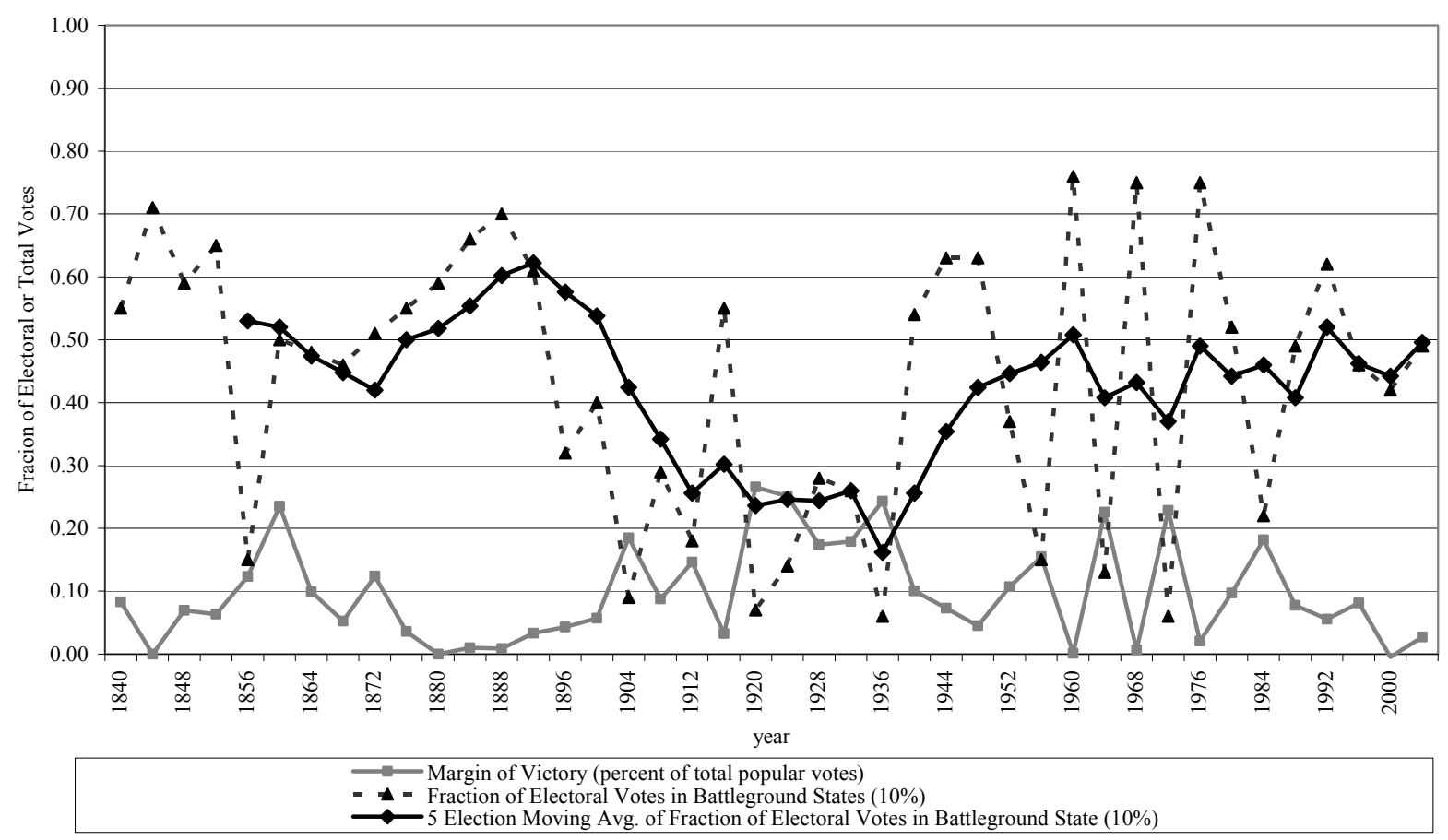

Note: Margin of Victory calculated as |(number of Democratic votes/total votes) - (number of Republican votes/total votes)|, Battleground calculated as (Margin of Victory) $\leq 10 \%$.

Sources: Clubb, et al (2005) 1840-1972; ICPSR (1995) 1972-1988; Dave Leip's Atlas of US Presidential Elections, $1992-2004$. 
Figure 2 -- County Level Dissimilarity and Isolation Indices for Whig/Republican and Democratic Presidential Votes, 1840-2004

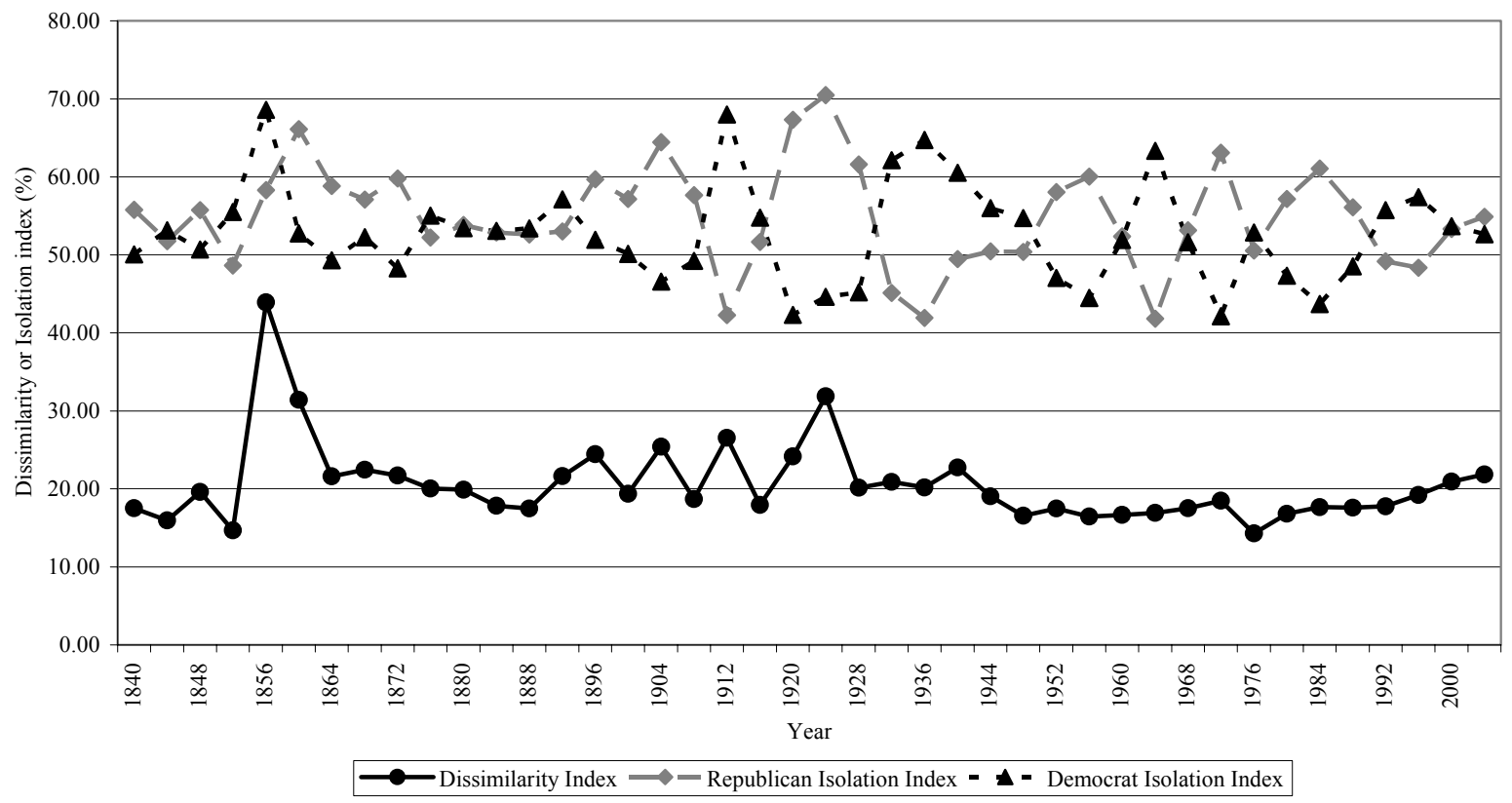

Notes: Dissmilarity index calculated by using: dissmilarity index $=(100 \%)^{*}(1 / 2) \Sigma \mid($ total vote Republican in a county/total vote Republican in US) - (total vote Democrat in a county/total vote vote Democrat in US)|, and the summation was over all counties within the United States.

Isolation index calculated by using: isolation index for republicans $=(100 \%) * \Sigma \mid($ total vote Republican in a county/total vote Republican in US) $-($ total vote

Republican in a county/total vote vote Democrat or republican in a county)|, and the summation was over all counties within the United States. A similar calculation is used for the Democrat isolation index.

Sources: Clubb, et al (2005) 1840-1972; ICPSR (1995) 1972-1988; Dave Leip's Atlas of US Presidential Elections, $1992-2004$. 
Figure 3 -- Persistence in Presidential Voting, 1860-2004

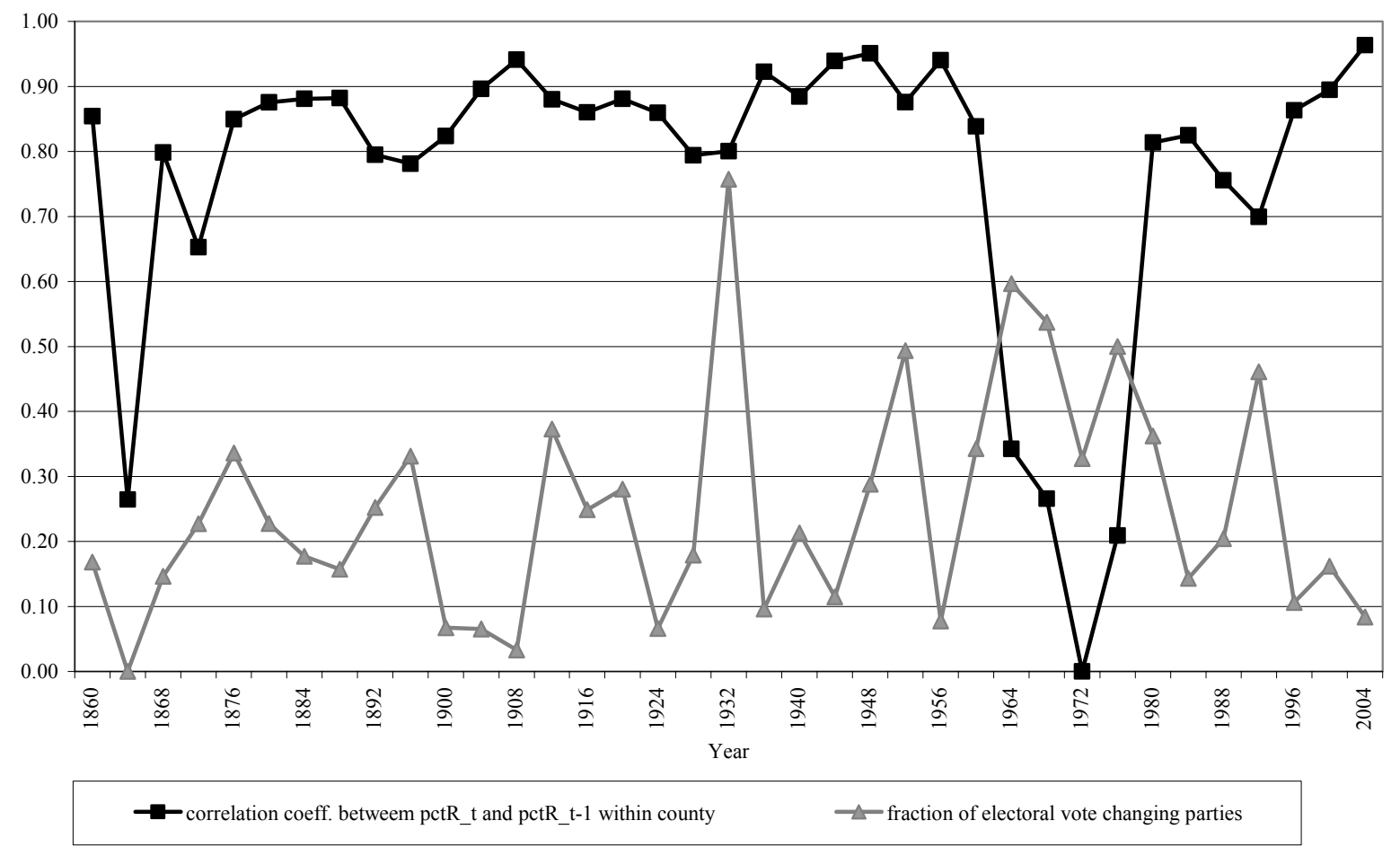

Note: Calculations take into account the change of state electoral votes for each election year.

Sources: Clubb, et al (2005) 1840-1972; ICPSR (1995) 1972-1988; Dave Leip's Atlas of US Presidential Elections, $1992-2004$. 
Figure 4 -- Political Partisanship, 1978-2004

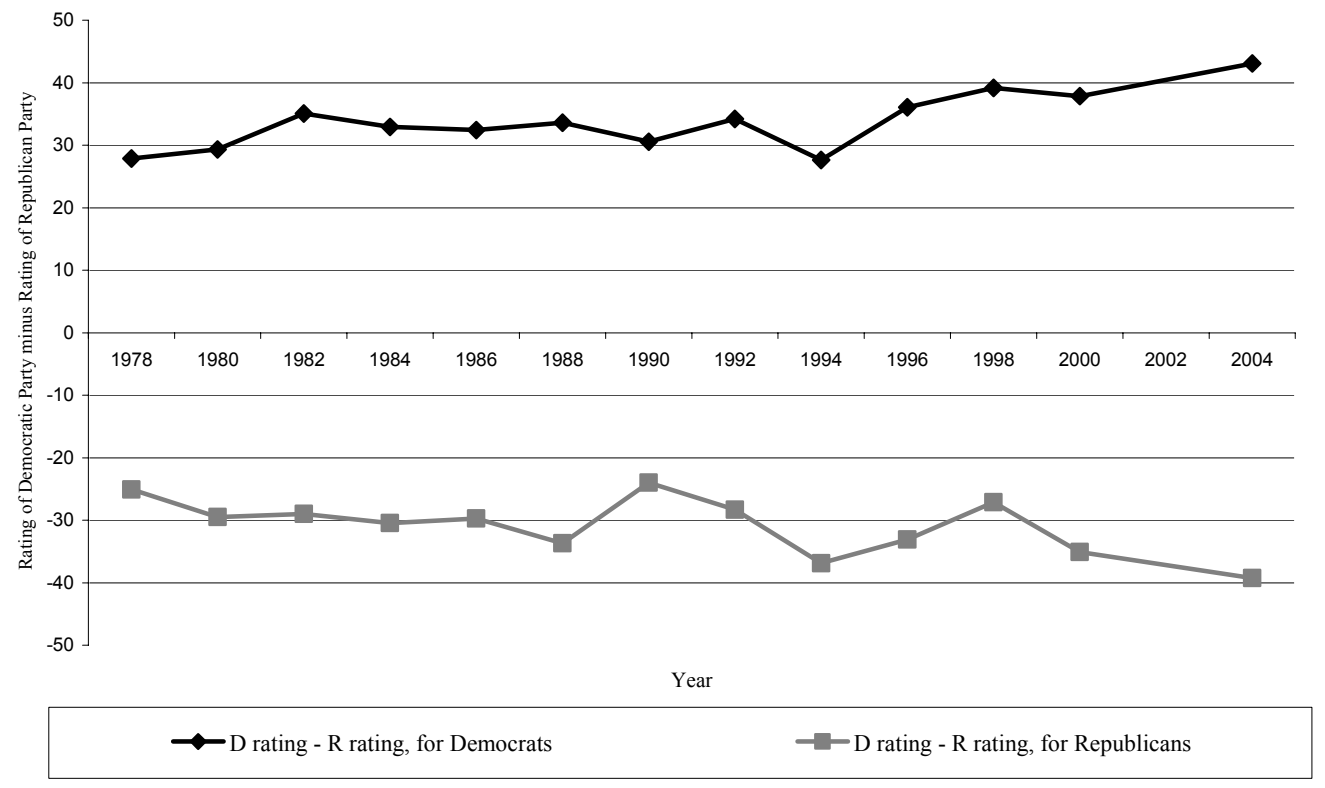

Notes: The party trend lines represent the individuals' thermometer rating of the Democratic Party minus their thermometer rating of the Republican Party averaged by their self-identifed party status.

Sources: American National Election Studies Cumulative Data File, 1948-2002 and 2004 National Election Study 
Figure 5 - Correlation between Share Voting for Kerry and Belief that AIDS is Punishment from God.

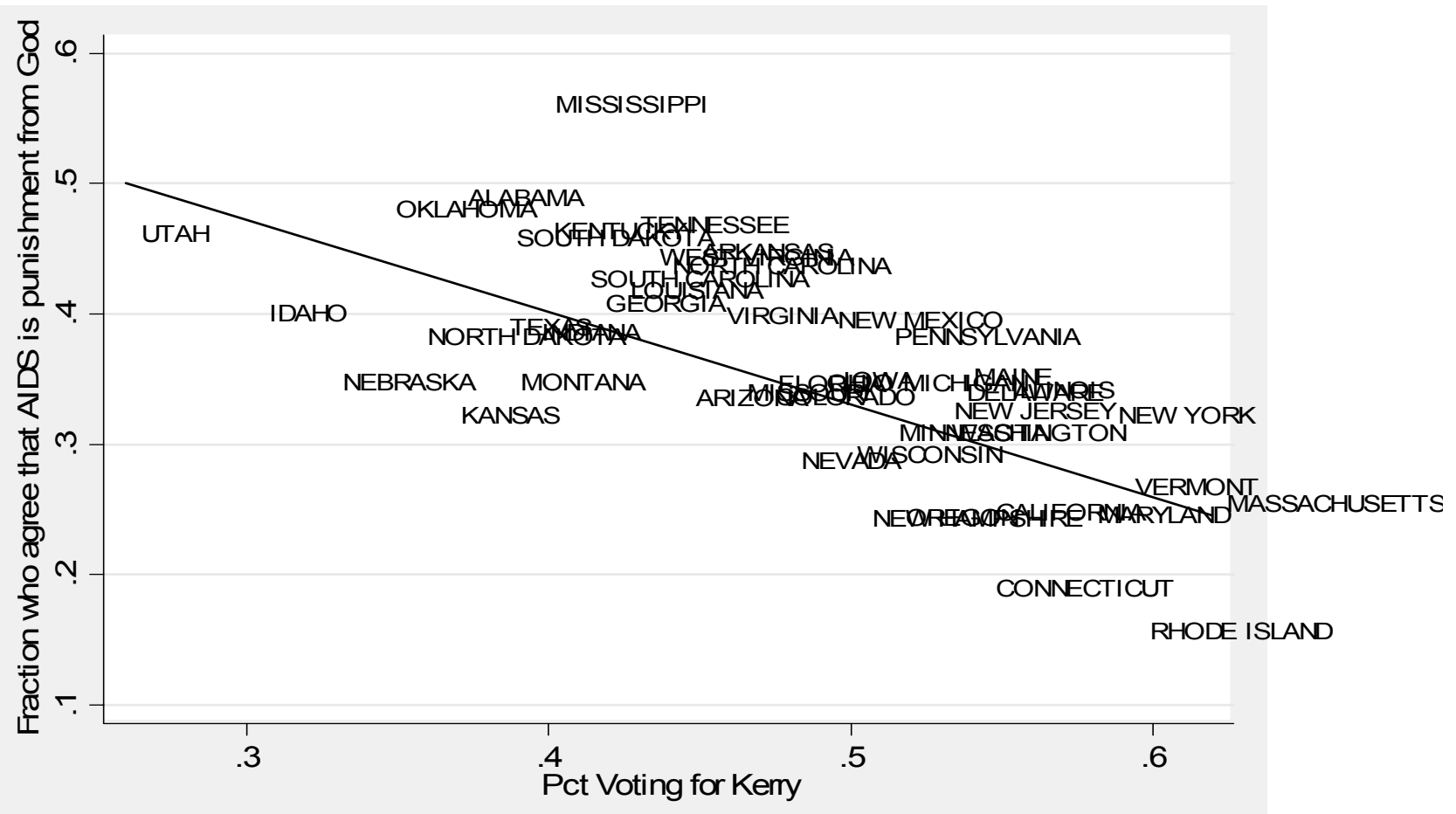

Sources: PEW 1987-2003 Values Survey (combined dataset); Dave Leip's Atlas of Presidential Elections 
Figure 6 -- Trends in the Determinants of Voting Republican, 1952-2004

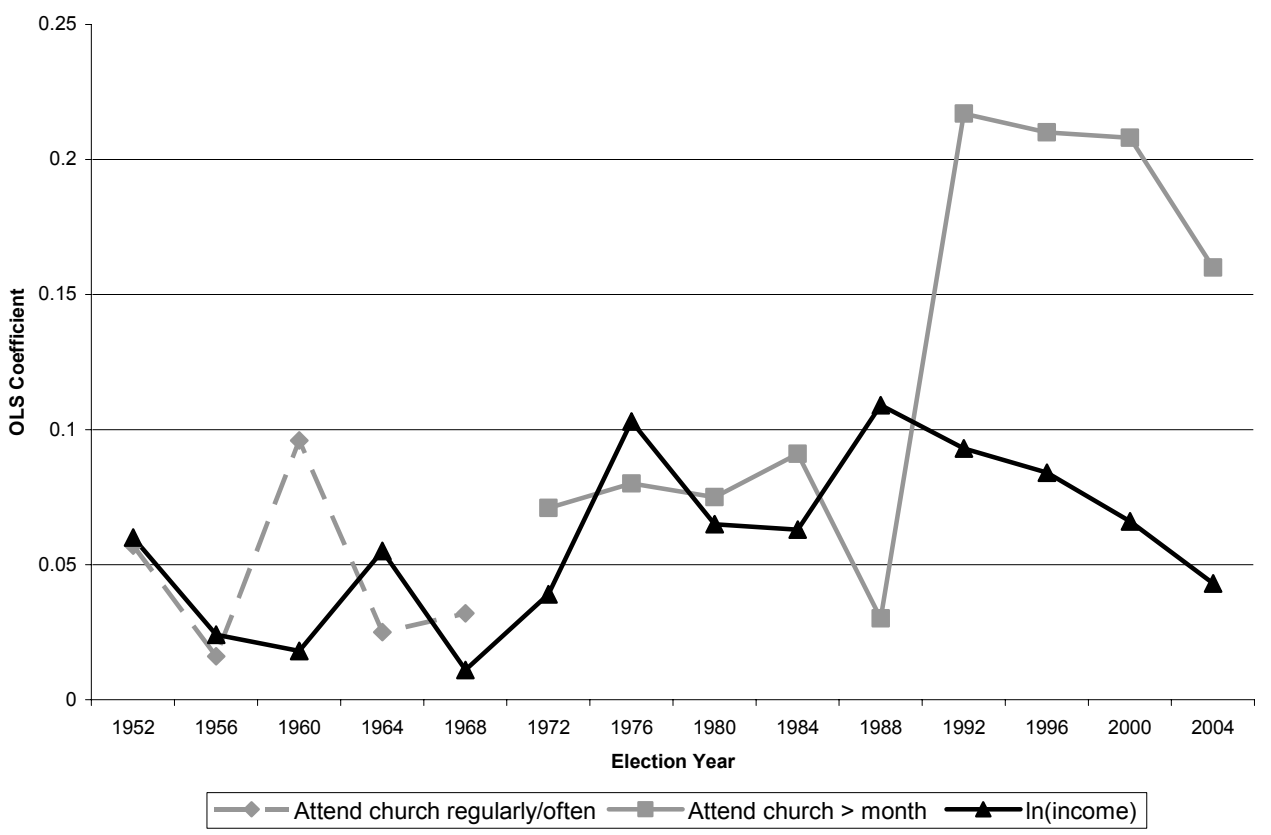

Notes - ANES 1952-2004. Coefficents are from OLS regression of probability of voting R on In of family income, dummy if attend church more than once a month (or regularly or often for years before 1970), age, age2, race, and a dummy for completing college. 
Figure 7 -- Relationship between In(Median County Income 1950) and Voting Republican

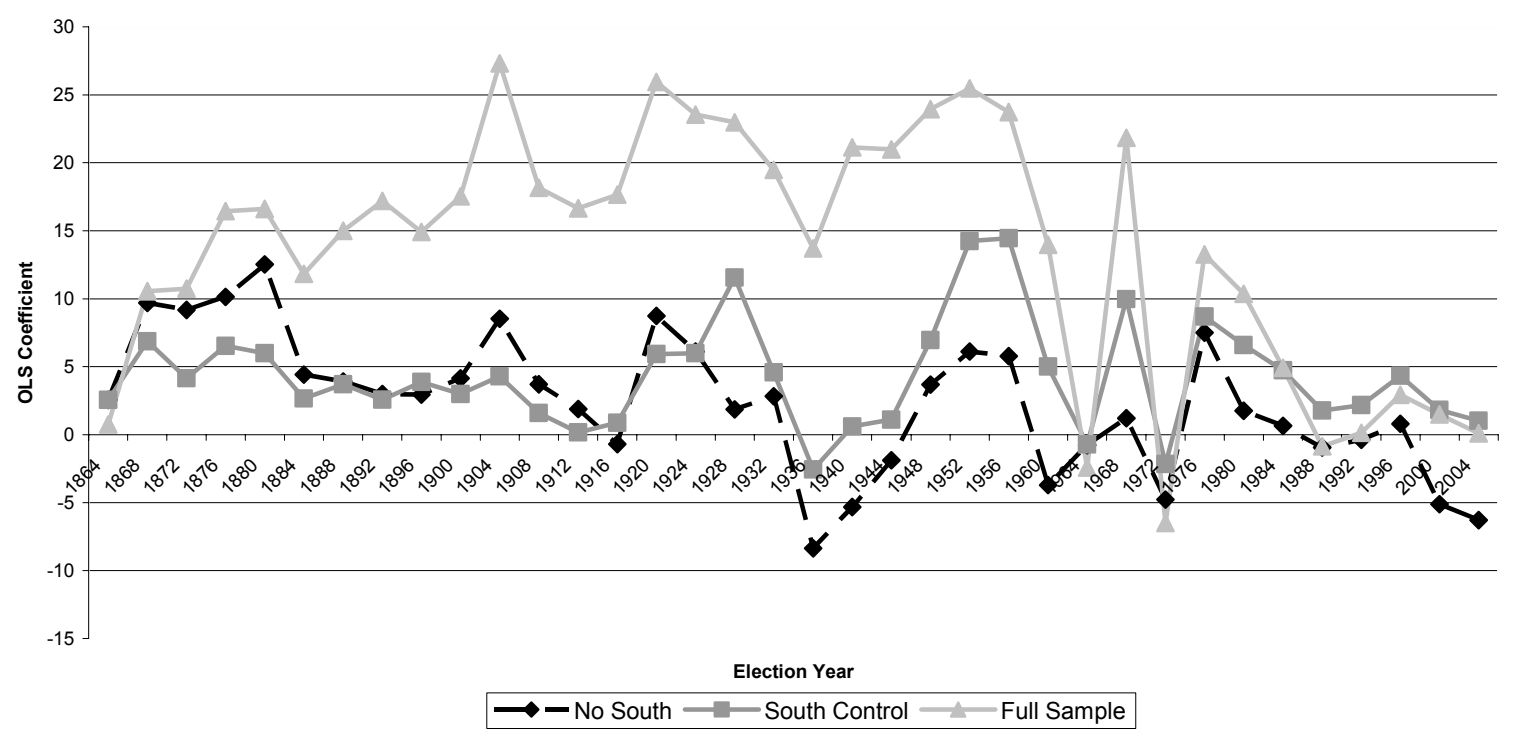

Notes -- Lines represent coefficients from univariate regressions of In(median county income 1950) on the share voting Republican. For 1912, we use the combined Republican and Progressive percentage.

Sources: Clubb, et al (2005) 1840-1972; ICPSR (1995) 1972-1988; Dave Leip's Atlas of US Presidential Elections, 1992-2004; Haines and ICPSR (2005); Bradley, et al (1992) 
Figure 8 -- Relationship between Religion and Voting Republican at the County Level, 1864-2004

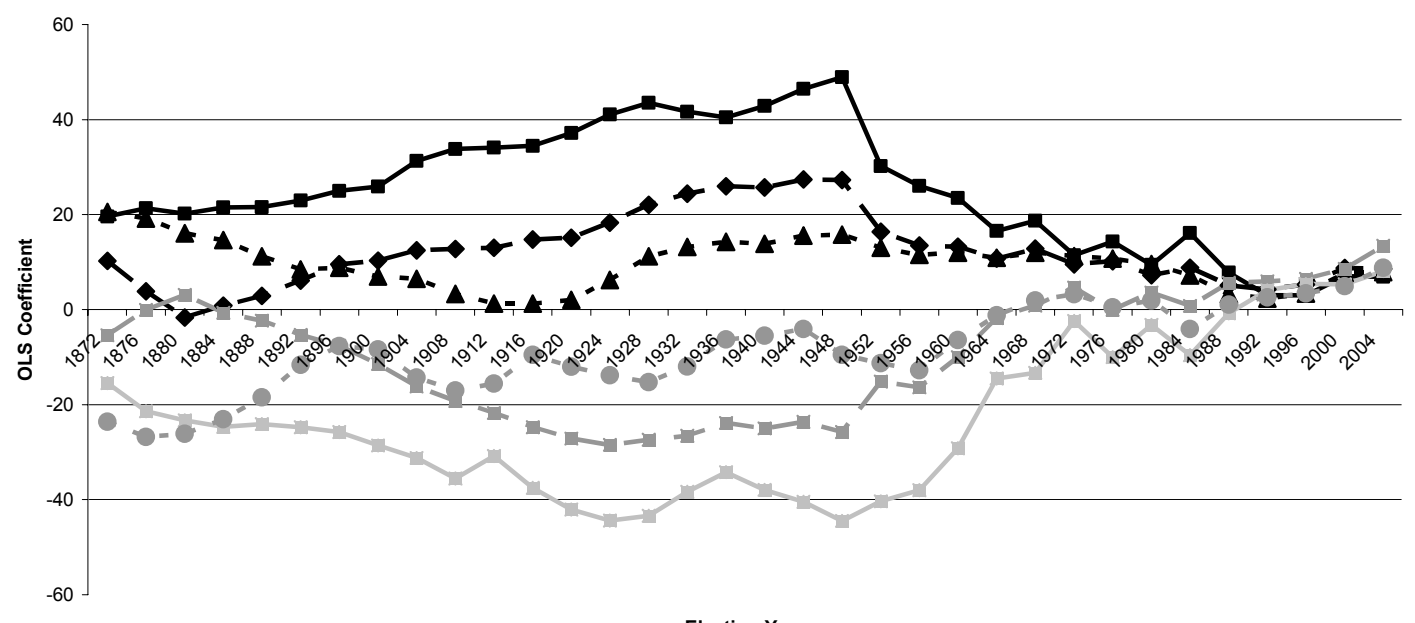

Election Year

\begin{tabular}{|c|c|c|}
\hline $\begin{array}{l}\longrightarrow \text { - Fract Mainline w/ South Ctrl } \\
- \text { - Fract Evang w/ South Ctrl }\end{array}$ & $\begin{array}{l}\longrightarrow \text { Fract Mainline w/ No Ctrl } \\
\text { Fract Evang no Ctrl }\end{array}$ & $\begin{array}{l}\text { - - Fract Mainline No South } \\
\text { - - Fract Evang No South }\end{array}$ \\
\hline
\end{tabular}

Notes -- Lines represent 3-election moving averages of coefficients from univariate regressions on the share voting Republican. Fraction of religious adherents computed for 1890, 1926, 1952, and 1990. Coefficients are computed using the closest year. For 1912, we use the combined Republican and Progressive percentage.

Sources: Clubb, et al (2005) 1840-1972; ICPSR (1995) 1972-1988; Dave Leip's Atlas of US Presidential Elections, 1992-2004; Haines and ICPSR (2005); Bradley, et al (1992) 


\section{Table 1 -- Heterogeneity in Beliefs, Behaviors, and Economic Conditions Across States}

A: Beliefs -- Fraction of state's respondents who agree wit
\begin{tabular}{|l|c|c|}
\hline 1. State & $\mathrm{N}$ & $\begin{array}{c}\text { Schools should fire } \\
\text { homosexual teachers. }\end{array}$ \\
\hline \hline Massachusetts & 430 & 0.23 \\
District of Columbia & 74 & 0.26 \\
Connecticut & 272 & 0.26 \\
Maryland & 449 & 0.27 \\
New Jersey & 588 & 0.29 \\
West Virginia & & \\
Oklahoma & 230 & 0.54 \\
Tennessee & 261 & 0.56 \\
Arkansas & 514 & 0.60 \\
Mississippi & 226 & 0.61 \\
\hline
\end{tabular}

\begin{tabular}{|l|c|c|}
\hline 2. State & $\mathrm{N}$ & $\begin{array}{c}\text { It is okay for blacks and } \\
\text { whites to date. }\end{array}$ \\
\hline \hline Kentucky & 339 & 0.35 \\
West Virginia & 230 & 0.40 \\
Tennessee & 497 & 0.41 \\
South Carolina & 322 & 0.43 \\
Alabama & 382 & 0.46 \\
& & \\
Oregon & 240 & 0.77 \\
California & 1860 & 0.77 \\
Delaware & 58 & 0.79 \\
Maine & 124 & 0.81 \\
District of Columbia & 74 & 0.88 \\
\hline
\end{tabular}

\begin{tabular}{|l|c|c|}
\hline & N & $\begin{array}{c}\text { AIDS is God's punishment } \\
\text { for immoral sexual } \\
\text { behavior. }\end{array}$ \\
\hline \hline Rhode Island & 83 & 0.16 \\
Connecticut & 243 & 0.19 \\
New Hampshire & 74 & 0.24 \\
Oregon & 226 & 0.24 \\
Maryland & 375 & 0.25 \\
Kentucky & & \\
Tennessee & 309 & 0.46 \\
Oklahoma & 438 & 0.47 \\
Alabama & 221 & 0.48 \\
Mississippi & 364 & 0.49 \\
\hline
\end{tabular}

\begin{tabular}{|l|c|c|}
\hline & & \\
4. State & $\mathrm{N}$ & $\begin{array}{c}\text { The best way to ensure peace } \\
\text { is through military strength. }\end{array}$ \\
\hline \hline District of Columbia & 77 & 0.36 \\
Vermont & 52 & 0.40 \\
Oregon & 257 & 0.42 \\
Delaware & 62 & 0.42 \\
Minnesota & 418 & 0.47 \\
& & \\
Idaho & 122 & 0.66 \\
Oklahoma & 265 & 0.68 \\
Mississippi & 281 & 0.69 \\
Arkansas & 230 & 0.70 \\
South Carolina & 330 & 0.73 \\
\hline
\end{tabular}

\begin{tabular}{|l|c|c|}
\hline & N & $\begin{array}{c}\text { When something is run by } \\
\text { the government, it is usuall } \\
\text { inefficient and wasteful. }\end{array}$ \\
\hline \hline District of Columbia & 77 & 0.45 \\
Mississippi & 292 & 0.51 \\
Delaware & 63 & 0.57 \\
Nevada & 87 & 0.57 \\
South Carolina & 339 & 0.58 \\
& & \\
Montana & 113 & 0.72 \\
Nebraska & 189 & 0.72 \\
Arkansas & 242 & 0.74 \\
Oregon & 262 & 0.74 \\
South Dakota & 71 & 0.77 \\
\hline
\end{tabular}

\begin{tabular}{|l|c|c|}
\hline 6. State & $\mathrm{N}$ & $\begin{array}{c}\text { We will all be called before } \\
\text { God on Judgement Day to } \\
\text { answer for our sins. }\end{array}$ \\
\hline \hline Vermont & 51 & 0.53 \\
Rhode Island & 96 & 0.60 \\
Oregon & 250 & 0.63 \\
New Hampshire & 88 & 0.65 \\
Nevada & 79 & 0.67 \\
& & \\
Tennessee & 492 & 0.92 \\
South Carolina & 299 & 0.93 \\
Oklahoma & 247 & 0.94 \\
Alabama & 377 & 0.94 \\
Mississippi & 266 & 0.95 \\
\hline
\end{tabular}

B: Consumption and Conditions:

\begin{tabular}{|l|c|}
\hline 7. State & Gallons of wine sold per capita, 2002 \\
\hline \hline West Virginia & 0.79 \\
Mississippi & 0.89 \\
Oklahoma & 1.01 \\
Arkansas & 1.05 \\
Iowa & 1.07 \\
& \\
Massachusetts & 4.18 \\
Nevada & 4.70 \\
Idaho & 4.94 \\
New Hampshire & 5.34 \\
District of Columbia & 6.49 \\
\hline
\end{tabular}

\begin{tabular}{|l|c|}
\hline 8. State & 2003 Median Household Income \\
\hline \hline Arkansas & 32,002 \\
Mississippi & 32,728 \\
West Virginia & 32,763 \\
Louisiana & 33,507 \\
Montana & 34,108 \\
& \\
Minnesota & 52,823 \\
Virginia & 54,783 \\
Connecticut & 54,965 \\
New Hampshire & 55,567 \\
New Jersey & 56,045 \\
\hline
\end{tabular}

Notes: Data for beliefs are from the Pew Values Survey 1987-2003 Merged File. The fraction agreeing is computed by combining individuals who completely or mostly agree and dividing that number by the total number of respondents. Data on wine consumption per capita is from NIH Publication No. 04-5563 (2004). Median household income is from the census.

Sources: PEW 1987-2003 Values Survey (combined dataset); NIH Publication No. 04-5563 (2004); U.S. Census Bureau 
Table 2 -- Historical Determinants of State Beliefs and State and County Voting Patterns

\begin{tabular}{|c|c|c|c|c|c|c|c|}
\hline & (1) & (2) & $(3)$ & (4) & $(5)$ & (6) & (7) \\
\hline & $\begin{array}{l}\text { AIDS is } \\
\text { punishment } \\
\text { from God }\end{array}$ & $\begin{array}{c}\text { Schools } \\
\text { should fire } \\
\text { homosexuals }\end{array}$ & $\begin{array}{l}\text { It is ok for } \\
\text { blacks and } \\
\text { whites to } \\
\text { date }\end{array}$ & $\begin{array}{l}\text { Prayer is } \\
\text { important } \\
\text { for daily } \\
\text { life }\end{array}$ & $\begin{array}{l}\text { Ensure } \\
\text { peace thru } \\
\text { military } \\
\text { strength }\end{array}$ & $\begin{array}{l}\text { Pct Voting for } \\
\text { Kerry }\end{array}$ & $\begin{array}{l}\text { Pct Voting } \\
\text { for Kerry }\end{array}$ \\
\hline $\begin{array}{c}\text { Percent of religious } \\
\text { aderents evangelical, } 1926\end{array}$ & $\begin{array}{c}0.13 \\
(0.070)^{*}\end{array}$ & $\begin{array}{c}0.11 \\
(0.110)\end{array}$ & $\begin{array}{c}-0.26 \\
(0.118)^{* *}\end{array}$ & $\begin{array}{c}0.13 \\
(0.067)^{*}\end{array}$ & $\begin{array}{c}0.18 \\
(0.070)^{* *}\end{array}$ & $\begin{array}{l}-0.014 \\
-0.079\end{array}$ & $\begin{array}{c}0.031 \\
(0.033)\end{array}$ \\
\hline $\begin{array}{l}\ln (1+\text { percent of population } \\
\text { slave in } 1850)\end{array}$ & $\begin{array}{c}-0.01 \\
(0.010)\end{array}$ & $\begin{array}{c}-0.01 \\
(0.016)\end{array}$ & $\begin{array}{c}0.02 \\
(0.017)\end{array}$ & $\begin{array}{c}-0.01 \\
(0.009)\end{array}$ & $\begin{array}{c}0.00 \\
(0.007)\end{array}$ & $\begin{array}{c}0.012 \\
(0.009)\end{array}$ & $\begin{array}{c}0.007 \\
(0.006)\end{array}$ \\
\hline $\begin{array}{l}\text { Percent of population } \\
\text { foreign born, } 1920\end{array}$ & $\begin{array}{c}-0.27 \\
(0.118)^{* *}\end{array}$ & $\begin{array}{c}-0.50 \\
(0.148)^{* * *}\end{array}$ & $\begin{array}{c}0.45 \\
(0.207)^{* *}\end{array}$ & $\begin{array}{c}-0.34 \\
(0.147)^{* *}\end{array}$ & $\begin{array}{c}0.06 \\
(0.157)\end{array}$ & $\begin{array}{c}0.242 \\
(0.139)^{*}\end{array}$ & $\begin{array}{c}0.413 \\
(.079)^{* * *}\end{array}$ \\
\hline $\begin{array}{l}\text { Share of pop }>10 \text { yrs } \\
\text { working in } \mathrm{Mfg}, 1920\end{array}$ & $\begin{array}{c}-0.28 \\
(0.060)^{* * *}\end{array}$ & $\begin{array}{c}-0.26 \\
(0.080)^{* * *}\end{array}$ & $\begin{array}{c}0.04 \\
(0.100)\end{array}$ & $\begin{array}{c}-0.23 \\
(0.092)^{* *}\end{array}$ & $\begin{array}{c}-0.16 \\
(0.068)^{* *}\end{array}$ & $\begin{array}{c}0.417 \\
(0.073)^{* * *}\end{array}$ & $\begin{array}{c}0.42 \\
(.096)^{* * *}\end{array}$ \\
\hline Constant & $\begin{array}{c}0.452 \\
(0.031)^{* * *}\end{array}$ & $\begin{array}{c}0.535 \\
(0.034)^{* * *}\end{array}$ & $\begin{array}{c}0.59 \\
(0.051)^{* * *}\end{array}$ & $\begin{array}{c}0.86 \\
(0.035)^{* * *}\end{array}$ & $\begin{array}{c}0.574 \\
(0.040)^{* * *}\end{array}$ & $\begin{array}{c}0.309 \\
(0.044)^{* * *}\end{array}$ & $\begin{array}{c}0.32 \\
(.023)^{* * *}\end{array}$ \\
\hline Observations & 47 & 47 & 47 & 47 & 47 & 47 & 2822 \\
\hline R-squared & 0.67 & 0.7 & 0.58 & 0.65 & 0.48 & 0.56 & 0.14 \\
\hline
\end{tabular}

Robust standard errors in parentheses

* significant at $10 \%$;* significant at $5 \%$;** significant at $1 \%$

Notes: All results are from OLS regresstions and exclude Alsaka, Hawaii, and Wyoming.

Sources: PEW 1987-2003 Values Survey (combined dataset) ; Dave Leip's Atlas of

Presidential Election; Haines and ICPSR (2005); 